\title{
Globalisation, Accounting and Developing Countries
}

Trevor Hopper ${ }^{\mathrm{a}}$, Philippe Lassou ${ }^{\mathrm{b}}$ and Teerooven Soobaroyen ${ }^{\mathrm{c}}$

${ }^{a}$ University of Sussex, UK

Stockholm School of Economics, Sweden

Victoria University of Wellington, New Zealand

Email: T.H.Hopper@sussex.ac.uk

Postal address: School of Business, Management and Economics

University of Sussex

Falmer, Brighton, UK

BN1 9SL

${ }^{\mathrm{b}}$ University of Southampton, UK

Email: p.j.lassou@soton.ac.uk

Postal address: Southampton Business School

University of Southampton

Highfield, Southampton, UK

SO17 1BJ

${ }^{\mathbf{c}}$ University of Essex, UK

\section{Corresponding author details:}

Email: tsooba@essex.ac.uk

Postal address: Essex Business School

University of Essex

Wivenhoe Park

Colchester, UK

CO4 3SQ 


\title{
Globalisation, Accounting and Developing Countries
}

\begin{abstract}
Accounting is an instrument and an object in globalisation but its impact and manifestation is not uniform across Northern developed countries and Southern developing countries (DCs). This paper reviews contributions on globalisation and its influence on accounting in DCs, and identifies important research gaps. It examines the role of accounting in changing development policies, from state capitalism through neo-liberal market-based to good-governance policies. It then considers specific accounting issues, namely the diffusion of International Accounting Standards (now International Financial Reporting Standards) and how they promote global neo-liberalism; the development of the accounting profession in DCs in the face of competition from Northern global accounting firms and professional associations; accounting issues in state-owned organisations, and privatised and multinational corporations; government accounting reforms and the resurrection of the state in DCs; social and environmental accounting issues; and the rise of non-governmental organisations and their accounting and accountability. The discussion and conclusions reflect on achievements to date and important areas requiring further development.
\end{abstract}

Keywords: accountability; critical; globalisation; accounting; development; governance. 


\section{Introduction}

Accounting may seem peripheral to development, which could explain the lack of attention it has received from development studies and accounting researchers, indigenous politicians with more pressing matters on hand and, to a lesser degree, institutions providing aid and finance to developing countries (DCs). Better accounting will not solve poverty but it is an essential, if neglected, cog in development mechanisms. Too often it is seen as a simple transference of technical systems, regulations, and concepts used in rich countries to poor ones. This masks a series of issues including their bias to Northern ideologies and interests, not least those of multi-national corporations (MNCs); ${ }^{1}$ insufficient recognition of indigenous circumstances, needs and participation; implementation problems; inequities of power; and an orientation to financial over development ends. Hence many accounting policies recommended and/or imposed by external institutions fail (Andrews, 2012). Too often the yardstick is whether DCs have adopted international accounting and auditing standards and allegedly best (i.e. Northern) $)^{2}$ practices, and failures to conform are attributed to cultural differences.

Despite work on accounting and development in the 1960s and 1970s (e.g. Enthoven, 1973) this topic became neglected. Socially- and politically-oriented accounting journals published little on DCs until the 1990s, e.g. Critical Perspectives on Accounting's first such paper was Asechemie (1997). He argued that agency theory, with its capitalist assumptions, failed to reflect accounting and labour processes in Africa. This brought a sharp rejoinder from Wallace (1997), a major pioneer of accounting and development research, who concurred that most contemporary Northern accounting theories are irrelevant to Africa. Subsequently, accounting research on globalisation and development increased. It often views globalisation negatively, expressing concerns that many reforms fail or have limited success, and that the voices, interests and needs of DCs are subservient to powerful Northern institutions' interests and hegemony; for instance, Esposito et al. (1998) and DiFazio (1998) claim that although globalisation could raise living standards, it has contributed to hollowedout welfare states, growing unemployment, and repressive employment conditions. Lehman (2009) argues that deregulation, outsourcing and privatisation are heralded because they

\footnotetext{
${ }^{1}$ For ease of presentation transnational corporations are included under the acronym MNC.

${ }^{2}$ The dichotomy between rich and poor countries is useful for analysis but it is crude and neglects gradations of affluence. The division is often labelled through the terms First World and Third World, Western and nonWestern, and the North and South. For ease of exposition this paper uses the latter terms.
} 
facilitate global markets but neglect values that bind societies together. Samuel and Manassian (2011) dismiss much international accounting research as a discursive exercise following decolonisation that continues to propagate 'Cold War' development doctrines and political programmes for a commodity-intensive world peopled by economic subjects.

Nevertheless, blanket condemnation of globalisation and accounting's role therein can occlude positive achievements and potential advantages of better integrating DCs into the global economy. Furthermore, there is a danger of 'ghettoising' development to poor countries although in many rich countries, income differentials and poverty are in fact increasing. Too often development policies implicitly assume that DCs should learn from rich countries but the converse can be true - e.g. micro-finance may help poor and marginalised sectors of society to be more politically engaged, and development aims such as empowering women, redistributing income, and creating jobs for the poor are, or should be, policy considerations in rich countries too.

Consequently, the paper identifies key characteristics of DCs and globalisation, and how globalisation (an unavoidable world scale phenomenon, see Wolf, 2003) is pertinent to accounting in DCs. Then it examines the role of accounting in changing development policies, ranging from state capitalism through neo-liberal market-based to good-governance policies. Next, it examines related accounting issues affecting DCs, namely the diffusion of International Accounting Standards (IASs) (now International Financial Reporting Standards (IFRSs) and their role in promoting global neo-liberalism; the development of the accounting profession in the face of competition from Northern global accounting firms and professional associations; accounting issues regarding privatised and state-owned organisations (SOEs), and MNCs; government accounting reforms; social and environmental accounting issues; and the rise of NGOs and concerns about their accounting and accountability. The discussion and conclusions reflect on achievements to date, theoretical perspectives employed and important areas for further development.

\section{Developing countries}

Defining a DC is fraught with difficulty. The World Bank (WB) uses Gross National Income criteria to categorise economies along four development stages: (a) low income (\$905 or less), (b) lower middle income (\$906 - \$3,595), (c) upper middle income $(\$ 3,596$ - $\$ 11,115)$ and (d) high income (\$11,116 or more). This is a useful and objective measure but it has problems. A mean (or a median) may disguise wide income disparity within a country, e.g. in 
oil-rich countries like Nigeria, produce a static analysis, and inadvertently bias findings towards problematic 'failing' states. WB indices are cruder than those of the United Nations (UN). The WB human development index (HDI) measures life expectancy, educational attainment and adjusted real income (\$ per person). It classifies economies into less developed countries (LDCs) (50), developing economies (168), economies in transition (20) and developed economies (42). This paper focuses on the first category of the HDI index but, where relevant, it includes data from other countries. Ex-communist countries in transition are excluded ${ }^{3}$ as they are often relatively affluent, may lie within Northern political and economic systems, and have a legacy of Northern institutions under revival. Nevertheless, like rich countries, accounting and development issues in DCs are relevant to them.

Globalisation impacts on DCs, where $80 \%$ of the world's population live (more than seven billion people). Many subsist on less than $\$ 10$ a day; nearly one half on less than $\$ 2.50$ a day; and more than 1.4 billion on less than $\$ 1.25$. Worldwide, 870 million people have insufficient food according to UNICEF, and 22,000 children die every day due to poverty. ${ }^{4}$ Economic poverty, hunger, high mortality rates, unsafe water supplies, poor education systems, corrupt governments, war, and poor sanitation constrain development. Direct aid i.e. cash and provisions - can alleviate such problems: a starving person cannot be more productive without greater sustenance; immediate relief is essential for natural and humankind-induced disasters; and often there is insufficient capital for infrastructure improvements such as digging wells. However, direct aid can only be a limited, temporary solution. If sustained it can create dependency; for example, refugees refusing to return home when safe for fear that access to food and services may be more uncertain or limited than in camps. Longer-run development must be sustainable; e.g. donations of mechanised boats for fishermen can be abandoned due to insufficient resources or expertise to maintain them. Direct aid may simply treat the symptoms rather than the causes of poverty; e.g. lack of natural resources and capital, unstable and/or ineffective governments, poor infrastructure such as transport and communications, inadequate education and expertise, corruption, barriers to trade, and dependence on foreign governments and/or businesses. Moreover, development is not restricted merely to economic growth but extends to improving literacy,

\footnotetext{
${ }^{3}$ See special issue of Management Accounting Research (2002, V.13, N.4) and Research on Accounting in Emerging Economies (supplement 2, 2014) for relevant work.

${ }^{4}$ These statistics are taken from https://www.dosomething.org/facts/11-facts-about-global-poverty, 27/05/2014 derived from secondary sources, namely Global Issues, Statistic Brain, One, and World Food Programme. Debates over estimates exist but few query their basic tenor. They tally with WB estimates.
} 
life expectancy, employment, governance, and reducing environmental degradation. These issues require accounting that goes beyond its traditional remit.

\section{Globalisation}

Accounting papers frequently refer to globalisation without defining it or considering its political and socio-economic ramifications, particularly for DCs (Poullaos, 2004). Globalisation first entered an American English dictionary in 1961 (Scholte, 2002), although the concept was used much earlier (Nissanke \& Thorbecke, 2006; Robertson, 1990). Subsequently, it has entered vernaculars across disciplines, and political and lay discourses. A constant theme of development policies, whatever their ideological hue, is how best to facilitate sustainable development and integrate poor countries into an increasingly globalised economy. Yet the definition of globalisation remains elusive - writers define it depending on their perspective, whether sociological-, economic-, political-, scientific-, or management/business-oriented (Guillen, 2001).

This paper defines globalisation broadly, as in economic geography, where it is associated with the growing mobility of goods, services, commodities, information, people and communications across national frontiers. It is most pronounced in banking and finance where information technology, global stock markets, futures, debt, derivatives, and interest rate swaps have accelerated the mobility of factors of production (Harvey, 1989; Lash \& Urry, 1994). Neo-liberal economists see globalisation as the "integration of markets for goods, services and factors of production" (Wolf, 2003, p. 393), and "the integration of national economies and the development of international markets" (Bordo et al., 1999:1). This presumes that increased flows of trade, capital, labour, and technology across national borders as well as accelerated transport and telecommunications developments create a competitive environment conducive to faster economic growth, allow laws of comparative advantage to operate (Goldin \&Van der Mensbrugghe, 1992; Nissanke \&Thorbecke, 2006; Wolf, 2003), and will shift the level of incomes in DCs towards those of richer countries (Sachs \& Warner, 1995). For example, an OECD study claimed that full trade openness would produce by 2002 an annual gain of US\$477 billion (in 1992 prices) of which US\$221 billion would accrue to DCs (Goldin \&Van der Mensbrugghe, 1992). However, although Northern countries espouse free trade, they can still place-restrict it; for example, although technological advances foster the global transmission of knowledge and spawn new producers of technology (Wolf, 2003), many DCs do not reap many of its benefits: rich countries' patent and copyright systems restrict DCs' access (Chang, 2007). 
Sometimes economic, political and cultural features of globalisation are conflated. Economic imperatives such as 'the deregulation of international capital flows and trade', 'a globally integrated economy', and 'globally integrated markets' stand alongside political ones such as 'global forms of governance' and 'the world-as-a-whole' (Bordo et al., 1999; Martens \& Raza, 2010; Robertson, 1990; Wolf, 2003). This recognises overlaps between globalisation, governance and international relations (Scholte, 2002), and that globalisation is not merely an economic phenomenon but also covers "technological developments, cultural exchanges, facilitated by ... freer trade [and] ... tourism and immigration, changes in the political landscape and ecological consequences" (Martens \& Raza, 2010, p.280). Economic globalisation and culture are "increasingly strategic issue[s] that has to be faced and properly managed" (Granell, 2000, p.90). A worry is that a neo-liberal approach reduces cultural issues to economic incentives, and imbues a market-oriented mentality that precludes alternative ways of thinking and imagining (McGuigan, 2005, p.229). For example, global marketing of products the American way (e.g. Hollywood) may push indigenous and national cultures (Kapur, 1997) towards a homogenised Northern culture (Everett, 2003).

Globalisation, however, is not inevitably driven by technological innovations, markets, and socio-political forces, as often depicted in popular writings, but is partly an outcome of policies from major global economy regulators, of which the Bretton Woods institutions -WB, the International Monetary Fund (IMF) and the World Trade Organisation (WTO) - are the most important (Kapur, 1997). Each has a different mission (the WTO - fostering trade; the IMF - maximising financial stability, and the WB - promoting development) although demarcation between their activities can be blurred (Friedrichs \& Friedrichs, 2002). Alongside the United Nations (UN) they form part of a complex nexus of interlocking transnational institutions covering banking supervision, payment and settlement systems, money laundering, securities commissions, corporate governance, market integrity and insurance supervision (Graham \& Annisette, 2012). Northern powers dominate these institutions (Chang, 2007) and their endeavours to integrate DCs into the globalised economy have been accused of following an agenda of modernism and neo-liberal economics (Friedrichs \& Friedrichs, 2002; Nissanke \& Thorbecke, 2006; Scholte, 2002), and imposing globalisation from above non-democratically (Stiglitz, 2003). However, they are not omnipotent, nor are their interventions necessarily adequate and coordinated. Global economic regulation can exacerbate instability, leave systems prone to crises, and be inadequate to deal with global threats, which has brought claims that "the current process of globalisation is unsustainable in the long run unless we introduce new institutions and 
policies able to govern it" (Borghesi \& Vercelli, 2003, p. 87). Globalisation can be more complicated than anticipated (Martens \& Raza, 2010) and it defies deterministic, linear, functionalist patterns of development (Robertson, 1990, p18).

Criticisms tend not to be about globalisation per se - it has always existed although it has accelerated - but about the process(es) invoked in its name. Scholte (2002) observes that, “on cross-examination most 'anti-globalization' protesters ... reject neoliberal globalization rather than globalization per se" (ibid. p 10). The concern is that DCs cannot control policies with risks and costs that are "significant for fragile developing economies and the world's poor" (Nissanke \& Thorbecke, 2006, p. 1338). Exposing DCs to external economic forces can reduce national sovereignty, render domestic macroeconomic management difficult, and reduce tax revenues, particularly where MNCs relocate to low tax jurisdictions or use international transfer pricing to their advantage. Richer economies may benefit most from free trade as it can render small- and medium-sized enterprises (SMEs) in DCs uncompetitive thereby stifling the growth of domestic firms; and it can encourage the overuse of natural resources, particularly when DCs have weak legal and regulatory systems, weak government agencies, and ineffective and sometimes corrupt political leadership. In many DCs, globalisation has not reduced poverty, inequality has increased, and it has had detrimental environmental impacts, prompting many academics, commentators and poverty reduction and environmental activists to seek change.

\section{The role of accounting in changing development policies}

\subsection{State capitalism}

During the 1950s and 1960s Marxist and liberal economists prescribed different development policies. Marxists espoused industrialisation through state central planning, public ownership of major enterprises, and economic protection through tariffs and currency controls. In contrast, liberal economists stressed free trade, markets, capital accumulation and sometimes democracy. The latter had little resonance with most African and Asian economies that lacked capital and were predominately agricultural. Consequently, upon gaining independence, many adopted socialist regimes, often upon external advice but also due to indigenous rulers' ideological preferences, and pragmatism given shortages of private capital, under-developed product markets, and limited human and physical resources. Parliamentary democracies were instituted but often were diminished or abolished under systems of presidential one-party rule or military dictatorships. However, both development approaches promoted economic growth and were economic, linear and modernist: local 
tradition and culture was perceived as an impediment and its sacrifice a necessary if painful outcome.

International bodies like the WB and IMF supported state-led industrialisation. Large SOEs were created with boards nominated by ministers. The intention was for ministers and planners to set policy and for managers to execute it. The assumption was that central state planning would occur within a legal rational bureaucracy. The backbone of accountability and regulation lay in audited financial accounts to ascertain the accuracy of financial records and whether expenditure was disbursed as planned. These were to be fed back through Ministries to Parliament and potentially to the public. Iterative budgeting would coordinate central plans with those of SOEs; and timely and reliable accounting information would help ministries and SOEs allocate resources according to relative returns and development priorities and monitor managers' achievements of plans. Massive state investments in manufacturing SOEs and infrastructure in cities followed - rural agriculture received little attention - despite employing $60 \%$ of the workforce.

Initial accounting research endorsed central state planning, public ownership and industrialisation in DCs and recommended improving indigenous accounting capacity, data provision, and developing accounting education within a self-governed accounting profession (Enthoven, 1982; Ndzinge \&Briston, 1999; Needles, 1976; Seidler, 1967; Seiler, 1966 ) through a sub-plan within an overall economic plan (Needles, 1976). In retrospect these contributions were admirable if somewhat Utopian. An exception was Ghartey (1985), who claimed that African governments' monopoly of power, bureaucracy, conflicting policies, ineffective institutional structures, and cronyism would render accounting marginal and ineffective; poverty and dominant elites' lack of motivation would stymy adoption of technologically advanced systems; and cultures based on extended families would bring corruption, malpractice; and that the ensuing uncertainty, fear, tension, and insecurity would produce recurring crises. In short, he counselled that effective accounting requires good governance.

Some countries that successfully developed, e.g. South Korea, adopted such accounting changes but events transpired differently in many DCs often prone to economic, social and physical crises, political instability and regime changes. A recurring research finding is that whilst basically sound accounting and accountability systems were often adopted and maintained, in actuality they played a ceremonial role to gain legitimacy from the populace and external funders, and played little part in ministerial and parliamentary scrutiny or decisions. Meaningful accountability often never occurred (Alam, 1997; Hoque, 1995; Hoque \& Hopper, 
1994; 1997; Uddin \& Hopper, 1999). Political not legal rational bureaucratic or economic criteria were dominant: filling positions, awarding contracts, state sell-off of assets and operating decisions became subject to patronage by politicians seeking to bolster political support or to further their material interests. Many DCs took advantage of the 'Cold War' and played off communist and Northern donor countries to secure aid often more oriented to securing political allegiance than poverty alleviation (Hopper et al., 2009). State capitalism in action bore little correspondence to its ideals. Accounting unrelated to rewards or actual circumstances became irrelevant to managers in SOEs when political interventions predominated. Formal accounting mechanisms - usually technically sound albeit dated remained intact but became rule-bound, ceremonial, irrelevant rituals. Politicians retained them to maintain a veneer of legal rationality to secure legitimacy from external bodies and the populace (van Helden \& Uddin, 2016) but they and central planners paid little heed to accounting, setting higher but unrealistic budget targets to demonstrate political prowess. Dissatisfied managers either sought more budget participation and flexibility (Maunders et al., 1990), or resisted granting undue deals on ethical and/or commercial grounds but many recognised their weakness, disregarded budgets, and struck informal deals with local trade union leaders, workers, and suppliers to maintain production, whilst manipulating budgets to protect their reputations. Eventually, however, politicians found their space for political manoeuvre increasingly constrained as ballooning SOE losses and large public sector deficits resulted in fiscal crises of the state. Many DCs had to turn to donors and transnational financiers for relief.

\subsection{Neo-liberal policies}

DCs became increasingly aid-dependant and had to adopt development policies advocated by affluent nations (in the North), transnational financiers, particularly the WB and its acolytes, and often their former coloniser. The cessation of 'Cold War' politics ended benign loans for client states and right wing ideologies like Thatcherism and Reaganism cast scepticism on economic aid unaccompanied by structural reforms. During the 1980s and 1990s, external funders regarded many states in DCs as too big and corrupt, and a block rather than facilitators of development. The assumption was that state bureaucracies were inflexible, uncreative, rule-bound, and often corrupt. International financiers, frustrated with DC governments' failure to deliver services to the poor, turned to market capitalism inspired by neo-classical economics, including agency theory, 
transaction cost economics, and 'Friedmanite Chicago' neo-liberalism. Put crudely, the state was seen as the problem not the solution. The aim was to replace political factionalism and patronage with private ownership and market exchanges. Aware that fiscal crises precipitate political crises, LDC governments knew they must (or appear to) comply.

Loans to rectify fiscal imbalances of DCs became conditional on adopting 'one-size fits all' policies incorporating privatisation, deregulation, open markets, free trade, limited government intervention, attracting private capital, and public sector reforms within structural adjustment policies (SAPs) (Boli \& Petrova, 2007; Cook \& Kirkpatrick, 1995; Vreeland, 2003). The aim was to create conditions conducive for international finance capital and capital markets by eliminating subsidies, price controls and import barriers; reorganising and lessening public ownership of domestic banks; promoting private banks and domestic capital markets; privatising or closing SOEs; introducing 'new public management' (NPM) in government agencies; and legislating to force trade unions (particularly public sector ones) into collective bargaining, sever party links, and curtail labour rights, particularly in export zones. Private firms or non-governmental organisations (NGOs) rather than the government were contracted to deliver services. The aspiration was for a smaller state to play a greater supply-side role, follow legal-rational not partisan decision making, and create infrastructures conducive to market capitalism. This required changes to improve law and order and to protect property rights; fostering financial and commercial mobility; education and training congruent with market needs; regulatory bodies, particularly for privatised utilities where monopolies prevail; and political parties competing to deliver such regimes.

Accounting is crucial to market-based reforms, although often neglected by the IMF and WB whose policy officers have been, until recently, predominately macroeconomists. They tended to assume that accounting was a technical matter. Accounting reforms usually followed the advice and reports of accounting professional bodies (indigenous and international); transnational accounting and auditing standard setters (IFAC and the $\mathrm{IASB}^{5}$ ); and the Northern accounting industry, particularly the 'Big $4^{6}$ ' accounting firms (Hopper et al., 2009; 2012). It was presumed that increased competition and personal ownership in newly privatised companies, dictates of vitalised capital markets and regulators, company law reforms, building local professional accounting capacity and its regulation,

\footnotetext{
${ }^{5}$ International Federation of Accountants (IFAC); International Accounting Standards Board (IASB).

${ }^{6}$ Throughout this review the number of 'Big' accounting firms varies according to the date of relevant studies. We have used the number referred to by the authors, hence the variations in the paper.
} 
along with international accounting and audit standards would improve internal and external accounting reports and auditing, and thereby better lubricate capital market transactions and enterprise efficiency. Within government, NPM, which promulgates private sector accounting, was a major focus; however, the reality was that many DCs had insufficient local capacity and political support to manage ambitious, 'big-bang' reforms (van Helden \& Uddin, 2016).

Stiglitz (2002) argued that IMF 'solutions' worsen (even create) problems by unduly promoting global finance interests and creating fresh sources for neopatrimonialism to feed from, e.g. through sales of privatised companies and regulatory capture. SAPs had little success: on average, the performance of debtor country economies lagged behind those of the DCs without IMF loans (Welch \& Oringer, 1998); deregulation and suppression of trade barriers could erode tax bases (Aizenman \& Jinjarak, 2009); wages did not converge towards those in developed countries (Rama, 2002); labour's share of national income declined; changes in labour institutions (such as eroded minimum wages and trade union powers) contributed to greater inequality (Cornia, 1999); poverty and unemployment increased (Stiglitz, 2002); trade with developed countries lowered incomes (Meschi \& Vivarelli, 2009); local democracy was diminished; MNCs benefited - e.g. sometimes by purchasing SOEs at low cost (Narula \& Dunning, 2000); and the economic growth promised failed to materialise (McMichael, 2007), particularly for many poorer countries pursuing export-led growth strategies (Sannassee et al., 2014; Sawkut et al., 2009) . This is unsurprising for, somewhat ironically, rich countries did not follow neo-liberal policies to develop (Chang, 2007; Goldin \& Van der Mensbrugghe, 1992; Stiglitz, 2002).

From a neo-classical perspective, cheap labour is often the main competitive advantage of DCs but, paradoxically, rich countries maintained protectionist measures such as subsidies for locally-farmed produce - in accordance with GATT and WTO rules governing cheap labour in DCs threatening local businesses and farms (Lowder, 1999). This could wreak havoc in the agricultural sector of DCs. For example, "Somalia's pastoral economy was decimated by a structural adjustment programme of duty-free imports of subsidized beef and dairy products from the European Union" (McMichael, 2007, p.225); in Peru IMF debt conditions brought in cheap corn imports and inflated prices for farm inputs which bankrupted small farmers and intensified de-peasantisation (Chossudovsky, 2003); and Thai agro-exporting to international food processors brought 
short-term gains but subsequently limited income generation and food security, and resulted in increased volatilities for tomato producers (McMichael, 2007).

The results of accounting reforms were often disappointing (Andrews, 2012; Hopper et al., 2012; van Helden \& Uddin, 2016). It was not evident that adopting IASs had much practical effect beyond resident international firms or indigenous firms seeking foreign listings: auditing remained weak or corrupted; increased financial transparency and information did not materialise; policies, responsibilities and delivery of services became fragmented; accounting systems and regulations adopted to appease international agencies were often ignored; and civil servants suffering reductions in pay and numbers became at worst demoralised and more often less effective (Bakre, 2008; Chand \& White, 2007; Mir \& Rahaman, 2005).

\subsection{Good-governance policies}

Following the harsh critiques of neo-liberal policies, transnational development institutions and governments in rich and poor countries embraced a good governance agenda. It was realised that downsizing the state was an error. The WB (1992) identified governance quality as crucial for development, particularly the type of political regime; how authority is exercised when managing development resources; and its capacity to formulate and implement policies. Attention turned to the 'Capable State' and 'Good Governance' to complement market-based policies (World Bank, 1997), and many DCs committed to undertake such reforms voluntarily although they were often conditions for financial assistance (Chang, 2007).

Definitions of a capable state and good governance are often vague and varied, partly because some discretion is left with local policy-makers. Definitions can focus on means not ends. The agenda does not abandon macro-economic market-based reforms, encouraging private enterprise, and integrating DCs into the global economy, but it also focuses on building capacity and infrastructure to strengthen state institutions; protecting the most vulnerable, particularly the poor and women; safeguarding natural resources and the environment; combatting corruption and mismanagement; improving accountability and transparency; and protecting civil society and human rights (World Bank, 1997). The emphasis is on social justice and liberties; civil society ${ }^{7}$ involvement and influence, free and transparent

\footnotetext{
${ }^{7}$ Civil society organisations include NGOs, professional and private sector associations, trade unions, families, churches, and neighbourhood, social and work groups.
} 
information, press freedom, and rights to voluntary association. Undemocratic tendencies and poor government are seen as liabilities. The traditional economic approach to development has been re-cast in the shape of social or civic imperatives, e.g. improving 'governance' in rural settings; microfinance to empower the grassroots; and social entrepreneurship (Alawattage et al., 2015). Reforms often incorporate decentralisation to local governments and communities, e.g. through village development committees, commune accountability boards, and citizen complaint procedures. To increase the capacity of states, more donor funding has been directly placed into government coffers rather than to specific projects and delivery agencies. This has brought increased emphasis on securing better motivated, trained and remunerated civil servants who are more accountable and responsive to other stakeholders and comply with bureaucratic rules and regulations; meritocratic recruitment and promotion; and performance appraisal to develop a workforce of the right size, skills mix, motivation, and professional ethos, and sound government accounting systems supported by a robust accounting profession (Iyoha \& Oyerinde, 2010).

This must be seen in the context of the Millennium Development Goals established by UN members and 23 international organisations in 2000 for achievement by 2015 . The goals were to eradicate extreme poverty and hunger; achieve universal primary education; promote gender equality; reduce child mortality; improve maternal health; combat HIV/AIDS, malaria and other diseases; ensure environmental sustainability; and develop a global partnership for development. Each has specific targets and dates for its achievement. WB Worldwide Governance Indicators monitor 215 economies across six governance dimensions: voice and accountability; political stability and absence of violence; government effectiveness; regulatory quality; rule of law; and control of corruption. Each indicator can be broken down by country and topic. ${ }^{8}$ Considerable progress has been achieved, albeit unevenly.

Critics allege that good-governance policies are symbolic, subtle gestures that fail to address the substance of failed market reforms (Chang, 2007), and that democratic progress is often minimal due to donors' mixed commitment (Lynch \&Crawford, 2011). Nevertheless, such policies illustrate how the criteria and means of accounting for development extend into the social and political, and beyond economic growth and rising average incomes. Although conventional Northern accountability and accounting systems are still widely recommended,

\footnotetext{
${ }^{8}$ The topics are agriculture and rural development; aid effectiveness; climate change; economy and growth; education; health; infrastructure; energy and mining; poverty; gender; environment; private and public sectors; external debt; financial sector; science and technology; social development; social protection and labour; trade; and urban development.
} 
ideally these should incorporate greater democracy, civil society empowerment, decentralisation to local levels, transparency; and promote sustainability, poverty reduction and human rights. Whether this will occur is problematic.

\section{Contemporary issues in accounting and development}

5.1 International Accounting Standards, transnational institutions and the promotion of global neo-liberalism

The WB's Framework for International Financial Architecture (World Bank, 2001; 2005) seeks global standardisation through the adoption by governments of international accounting and auditing standards, modified accounting regulations for SMEs, better human resources to implement standards, and better public oversight of auditing (Graham \& Annisette, 2012). In so doing, Northern governments and transnational financial institutions still promote neo-liberal Anglo-American accounting. For example, they attributed the 1997-8 East Asian crisis to crony capitalism, poor financial governance, and insufficient transparency and they pressured DCs to align their financial infrastructures with international best practices. US Treasury Department officials argued that accounting harmonisation would increase global financial integration and extend Northern capital markets to DCs. Critics argue that this 'financialises' the world economy in the image of Anglo-American, financeled capitalism, and that such policies are inappropriate for a 'socially responsible' institution like the WB (Saravanamuthu, 2004), although Annisette (2004) claimed that was a naive interpretation, for it neglects the financial and institutional pressures driving the WB's pursuit of private international capital.

The WB and IMF rely on Northern professional accounting associations, 'Big 4' accounting firms, and transnational regulation and standard-setting agencies, particularly the International Accounting Standards Board (IASB) and the International Federation of Accountants (IFAC) for the technical detail within their general accounting recommendations. This has shifted the professional identity of standard setters towards satisfying transnational regulators and world governance institutions rather than national accounting regulation (Djelic \& Sahlin-Andersson, 2006, in Power, 2010). Botzem (2014) argues that the IASB is now the primary influence on global accounting although Samsonova-Taddei and Humphrey (2014) argue that national associations are still prominent and need strengthening to counter dominant Northern 'Big 4' accounting firms and professional associations. 
The International Accounting Standards Committee (IASC), founded in 1973, was originally a voluntary committee founded and funded by Northern professional associations inclined to traditional trusteeship who assumed they were the most appropriate agents to govern accountancy through issuing IASs. The IASC gained 140 member bodies from 104 countries, including many DCs. The IASB replaced it in 2001, following pressure from capital market authorities, particularly the US Stock Exchange Council (SEC) and the International Organization of Securities Commission (IOSCO), who wanted international standardisation to serve investors' needs. The IASB remains responsible for developing IASs and promoting their application. It is a private company: its board members are employees of a foundation funded by corporations, and some seats are designated for 'Big Four' accounting firms which are over-represented (Suddaby et al., 2007). Thus, its experts draw from the major accounting firms they police (Cobham \& McNair, 2012). Most trustees are from North America and Europe, as are eight of the 14 IASB members - representatives from DCs are minimal (Perera, 2012). The IASB's structure and membership has prompted questions about its legitimacy to set standards, the constituencies it serves, asymmetries of power, and the efficacy of standards adopted (Cobham \& McNair, 2012).

DCs' reaction to IASs has been diverse. Syrian accountants perceived globalisation and AISs as Anglo-American and imperialistic, a threat to the Syrian accounting profession and local jobs, and they anticipated problems in adopting and enforcing IASs without better training, but they believed globalisation could better their lives and the profession (Gallhofer et al., 2011). Elsewhere, studies suggest that universal standards usher in global capitalism with adverse consequences for DCs (Briston, 1978; Perera, 1989). For example, whilst capital markets welcomed China's adoption of the fair value accounting (FVA) it did little to advance the public interest or challenge political and economic forces in China (Zhang et al., 2012). South Pacific Islands had insufficient resources, skills and connections to capital markets to harmonise accounting practices (Chand, 2005). Fiji adopted IFRSs ${ }^{9}$ when influential MNCs and large international accounting firms claimed they would improve accounting's 'relevance' and 'accountability' but they mainly helped transfer economic resources to IFRS's proponents (Chand \& White, 2007). Whilst Boolaky (2012) argued that Mauritius has a socio-political and economic context which was conducive to IFRS development compared to many African countries, Northern standards and practices espoused neutrality and rational calculation which masked international capital flows in the

\footnotetext{
${ }^{9}$ The IASB's name for global accounting standards, previously called IASs by the IASC.
} 
case of Jamaica (Bakre, 2008). In Bangladesh, transnational institutions pressured the government and local accounting associations to adopt IASs to encourage foreign direct investment (FDI) but the slight local involvement brought poor adoption levels and domestic conflicts (Mir \& Rahaman, 2005). IFRS adoption by DCs is often advocated to attract FDI, but cross-country studies reveal conflicting evidence. For example, whilst a large-scale study of 124 countries found that FDI was positively associated with IFRS adoption (Gordon et al., 2012), Nnadi \& Soobaroyen (2015) found the opposite to be the case in Africa.

DCs often lack the technical expertise and influence to formulate IASs. Sadly, the IASB's consultation procedures have been labelled a legitimation strategy (Botzem, 2014). Even the WB has called upon the IASB to pay more attention to DCs, SMEs, and financial services to the poor; and the 2009 and 2010 G20 summits asked the IASB to improve the involvement of DCs, make standards more relevant for them, and increase access to financial services for the poor (Fyson, 2012). Critics of the IASB accuse it of neglecting Southern countries' concerns about intra-company trade, transfer pricing, global consolidation, crossborder invoicing, tax confidentiality, disclosing offenders, and low penalties for tax transgressions (Cobham \& McNair, 2012). UN members from DCs have not used their majority to challenge the international accounting regulation agendas of (minority) Northern nations (Rahman, 1998); however, regional alliances of accounting associations have grown, often involving DCs, such as the Pan African Federation of Accountants formed in 2011 with WB encouragement, the International Federation of Francophone Accountants formed in 1981, and the South Asian Federation of Accountants formed in 1984. Inter alia, they profess to help DCs make their case in processes of global harmonisation.

Perera (2012) divides the problems that DCs face when adopting IFRSs between general convergence issues and challenges to specific DCs. Convergence problems include nationalism; resentment of foreign influence; difficulties of gaining consensus; no universal acceptance of the need for such standards; their lack of differentiation to suit each DC's needs; naïve assumptions that they will produce comparable reports; the costs to familyowned indigenous businesses; and cultural differences, particularly when there is uncertainty over applications and different ethical values. Problems in specific DCs include difficulties in exerting professional judgement within a principles approach; inadequate qualified and experienced accountants and regulators; no established accountancy profession; reconciling standards with national economic planning; insufficient government involvement; and weak legal systems. When Andrews (2013) examined 20 IMF and WB Accounting and Auditing Reports of Standards and Codes in Africa since 2003, he found that their Northern-centric 
prescriptions neglected local needs, cultural differences and context, were too complex, and met the needs of capital markets and business rather than those of the state and central planners. Failure to satisfactorily address such issues means that IASs are adopted but not enforced (Fyson, 2012). Nevertheless, donors and the WB still assess accounting progress in DCs by their legal adoption of international accounting and auditing standards; the accounting profession's formal regulation of compliance; businesses' and accountants' commitment to these issues; and formal provision of accounting education and training (Andrews, 2013; Fyson, 2012).

Auditing standards are the province of IFAC, a Swiss-registered NGO, formed in 1977 at the $11^{\text {th }}$ World Congress of Accountants. It has 158 member bodies and associates in 123 countries, representing over 2.5 million accountants (Perera, 2012). Its mission is to serve the public interest, and strengthen the accountancy profession worldwide through highquality professional auditing. The IFAC is responsible for international standards on auditing ethics, accounting education and training, and public sector accounting. Its emergence stemmed from powerful regulators, particularly the WB, the IOSCO and the European Commission (EC), which saw the governance of auditors as of increasing global importance. Arguably, its membership is more open, and it pursues the public interest, ethics, and Southern countries' needs more than the IASB does. For example, following WB complaints of their neglect of DCs, IFAC launched the International Forum on Accountancy Development in 1999 to promote transparent and high-standard financial reporting by accounting and auditing professionals in DCs (Perera, 2012). The IFAC's Professional Accountancy Organization Development Committee's plan for 2011-2014 seeks to strengthen professional accountancy organisations in DCs. ${ }^{10}$ However, changes to IFAC's membership and governance have increased the influence of large Northern accounting firms and Northern regulators, and diminished IFAC's "public interest" commitments and global strategies for auditor regulation and public oversight (Humphrey et al., 2009; Loft et al., 2006). For example, the re-emergence of self-regulation in modified regulatory partnerships between transnational accounting firms, public oversight boards and large national

\footnotetext{
${ }^{10}$ Its current objectives are: to develop accountancy professions' capacity to produce high-quality financial information and management systems that support financial stability, economic growth, and social progress; increase awareness and knowledge sharing on adopting and implementing international standards; and improve development partnerships with the international donor community, regional organisations, and public and private sector stakeholders.
} 
accountancy bodies constrains global regulation in bank auditing, the status of auditing, and auditors' ability to pursue public interest issues (Humphrey et al., 2009).

Ultimately IFAC seeks harmonisation but their prescription of Northern auditing and corporate governance practices can prove inappropriate as they presume (often unwisely) that efficient capital markets, investor sophistication, effective regulators and legal systems prevail in many DCs. For example, in Bangladesh, compliance with and enforcement of auditing standards is weak as family-controlled firms predominate, there is easy access to bank credit, and auditors are poorly skilled (Siddique, 2012). DCs often adopt auditing standards to comply with loan conditions and gain legitimacy, although some DCs with strong accounting capacity and infrastructure, such as China, are challenging Northern domination. For example, the IASB permitted only the acquisition method of accounting for business combinations based on FVA but Chinese standard setters created two methods (Baker et al., 2010). When the FASB and the IASB prohibited the pooling of interests for business combinations, Chinese standard setters accepted this but perceived it as an attempt to make Chinese capital markets resemble those in Northern economies (Zhang et al., 2012).

The WTO has also helped to create a global market for accounting and auditing services. After extensive lobbying from transnational accounting firms, industry, and the USA, the WTO's General Agreement on Trade in Services and the Disciplines on Domestic Regulation in the Accountancy Sector abolished domestic regulations perceived as barriers to trade and investment. This impaired DCs' scope for domestic regulation on national and subnational licensing, accountants' qualifications, the scope of their work, their organisation as businesses, and adoption of non-harmonised technical standards. This has in turn constrained DCs' ability to protect their fledgling local profession, leaving large Northern accounting firms free to pursue their interests (Arnold, 2005; Suddaby et al., 2007). Whether this improves broader development goals is questionable; for example, whilst financial development improves asset allocation and is linked to economic growth in DCs, it may inhibit poverty reduction by diverting funding to large enterprises that have collateral rather than to smaller, poorer firms (Hossain et al., 2012).

5.2 The Accounting Profession: developing local capacity in the face of Northern global accounting firms and professional associations

Donors seeking to promote FDI and the private sector in DCs have prioritised stronger regulation by local accounting professionals, but accounting is increasingly 
globalised and dominated by large accounting firms (Samsonova-Taddei \& Humphrey, 2014). These interested parties have convinced regulators that external audits by global firms generate greater trust, surveillance and regulation of international enterprises (Hanlon, 1994) and they actively lobbied the WTO for a global market in accounting and auditing services. This can marginalise national accounting qualifications and licensing. In contrast, it has helped Northern accounting firms to shift the boundaries of professional regulation; gain new national markets and customers - e.g. NGOs and transnational financial institutions (Arnold, 2005); diffuse an Anglo-American model of universal professionalisation (Poullaos \& Uche, 2012); and re-produce globalisation in everyday managerial practices (Barrett et al., 2005).

Northern professional accounting associations, once primarily national, now compete to become global through examinations and membership in foreign countries, mutual recognition agreements, and partnerships with other national associations. Many have entered capacity-building projects in DCs, often financed by the WB. This can benefit DCs with weak accounting expertise and institutions, but the motives of the Northern accounting industry may be neither altruistic nor socially desirable (Arnold \& Sikka, 2001; Power, 1994). Their pursuit of international harmonisation of accounting knowledge carries dangers for DCs (Samsonova-Taddei \& Humphrey, 2014). For example, syllabi reproduce Northern values, systems and priorities, but neglect issues pertinent to DCs (Poullaos, 2012). Such harmonisation is also lucrative and enables Northern associations to extend their membership and credentials, frustrate development of rival indigenous associations, exert greater influence upon growing independent oversight and transnational regulation, and further the case for globally integrated accounting and auditing standards (Samsonova-Taddei \& Humphrey, 2014).

Histories of accounting professionalisation ${ }^{11}$ deliver a note of caution. The South African accounting profession helped maintain apartheid (Catchpowle \& Cooper, 1999; Hammond et al., 2009; 2012); and accountants assisted imperial governance and control over indigenous, slave and settler populations (Annisette \& Neu, 2004). Few ex-colonies' accounting professions are free from the legacy of empire: colonial professions and their members can still dominate practice, often to the exclusion of indigenous accountants (Poullaos \& Uche, 2012; Sian, 2011). After independence, many DCs sought to establish national accounting bodies to redress shortages of accountants and the imperialistic domination by Northern accounting firms and professions. However, these initiatives mostly

\footnotetext{
${ }^{11}$ For example, see the special issue Critical Perspectives on Accounting on Accounting and Empire (2004).
} 
faltered due to rivalries between locally and externally credentialed accountants and associations [sometimes divided on ethnic lines (see Annisette, 2003)], and large Northern international accounting firms and associations seeking to preserve their global influence. For example, conflicts endured between a Malaysian accounting association supported by the (then) 'Big 6' firms and a local association supported by smaller local firms over national accounting standard setting (Susela, 1999). Ethiopia's communist government made accountants government employees but the return to a market-oriented economy in 1991 brought pressures for a more autonomous accountancy profession. The Association of Chartered Certified Accountants (ACCA) used its fifty-year influence over Ethiopia's accountancy to control the Ethiopian Professional Association of Accountants and Auditor's training and certification (Mihret et al., 2012). In Trinidad and Tobago, the ACCA, which had dominated certifying professional accountants, collaborated with local accounting elites to subvert the government's goal of indigenising accountancy training (Annisette, 2000). Jamaica hit similar problems involving the ACCA when attempting to establish a local professional body (Bakre, 2006). In 1988, the Commonwealth Caribbean chartered institutes agreed to create an independent regional accountancy association in the belief that foreign accounting education and training programmes, particularly British ones, did not serve their needs, but transnational accounting professional bodies and firms - particularly the ACCA blocked this in order to retain their Caribbean market. Even the developing of university accounting education appropriate to local needs can be hampered by accounting academics allied to a foreign profession (Venter \& De Villiers, 2013). Such events have been labelled manifestations of imperialism, neo-colonialism, and globalisation (Bakre, 2014).

This, however, is not inevitable. Philippine legislators removed certified public accounting from Americans (Dyball et al., 2007). Expatriate British accountants dominated accountancy in colonial Kenya to the exclusion of African Kenyans and the marginalisation of Asians. After independence affirmative actions, social reforms, and new accountancy education and training programmes introduced by the government reversed exclusionary recruitment and facilitated entry of Africans, although their full acceptance and integration remain distant objectives (Sian, 2007). However, a governmental attempt to create a national accounting profession does not guarantee its independence; for example, in China, a powerful and ideologically-driven state strongly influences the accounting profession (Yee, 2012), and the state co-opted the emergent Brazilian accounting profession (1902-1946) (Agrizzi \& Sian, 2015). 
A counterweight to the dominance of the Northern accounting industry may lie in the growing global alliances of national professional associations, e.g. the Global Accounting Alliance and the Edinburgh Group. These include many DCs' associations - e.g. in Bangladesh, Sri Lanka, India and Pakistan - whose aims vary. Some seek to establish a 'global elite'; others to grant peripheral bodies - particularly in DCs - more voice in transnational regulation; and some use generous WB funding to increase accounting capacity in DCs by establishing or strengthening local associations (Samsonova-Taddei \& Humphrey, 2014). For example, the Swedish Development Agency is helping build stronger international partnerships to strengthen regional accounting associations in DCs (Fyson, 2012).

The activities of the Northern accounting industry in DCs are under-researched and thence difficult to assess. Poullous and Uche (2012) suspect that in some jurisdictions they have brought division and fostered their interests at the expense of local provision of financial services and credentialing, have introduced inappropriate syllabi, and have impeded education and training in vital areas such as technician and tertiary education. However, lack of local political will, domestic divisions and poor standards have also hindered strengthening of DCs' accounting professions and weakened DCs' voices in the international arena.

\subsection{Propagating private ownership:, privatisations and multi-national corporations}

As noted, many DCs sought to industrialise through state central planning and nationalisation policies which often produced fiscal crises (Hopper et al., 2009). Consequently, privatisations became frequent conditions of SAPs and remain a major plank of development policies. They are a panacea for their advocates but problem-ridden for critics (Josiah et al., 2010). Assessing the relative performance of SOEs and privatised corporations in DCs is difficult but the evidence that private enterprises outperform SOEs is inconclusive (Commander \& Killick, 1988; Cook \& Kirkpatrick, 1995; Uddin \&Hopper, 2003).

Critics claim that privatisations yielded opportunities for undervalued sales, e.g. of state-owned shares in China (Ding \& Graham, 2007); and excessive returns for owners where weak markets and little competition prevail (Megginson \& Sutter, 2006; Parker \& Kirkpatrick, 2005). The WB, IMF and Northern donors like USAID have been accused of ignoring local resistance to privatisation; employing inadequate financial systems for equity sales; ignoring local needs; and neglecting adequate regulation. Moreover, privatisations may not break undue political involvement with commercial organisations: it can find new avenues such as regulatory capture and tolerating financial irregularities (Hopper et al., 2012; Wickramasinghe \& Hopper, 2005). 
Advocates of privatisation presume that private ownership and competition induce improved management information and performance evaluation systems, enhance marketfriendly products and services, and attract greater investment in marketing, operations and staff development (Hopper et al., 2012). Generally this is correct. Privatisations tend to bring more accurate, quicker computerised internal controls that improve market information and short-run planning, and match production to market demand (Hopper et al., 2009) but whether this invariably serves development goals is questionable. For example, a WB report on newly privatised companies in Bangladesh claimed that their success warranted further privatisations but independent research judged only one a commercial success and it questioned the narrow criterion in the WB report-namely profitability (Uddin \& Hopper, 2003).

Proponents of privatisation argue that efficiency benefits trickle down to employees and ultimately society. However, a Bangladeshi privatisation redistributed power and wealth to new owners who exercised direct and arbitrary control, casualised labour at lower remuneration, brought opaque financial disclosure, and reduced tax revenues (Uddin and Hopper, 2001). Similar results have been noted elsewhere, such as in South Africa (Catchpowle \& Cooper, 1999) and in Ghana (Rahman et al., 2004); however, reports are not invariably bleak. The Ghanaian government's and the WB's and IMF's assessment of two privatisations claimed that financial improvements, better customer service, improved internal business processes, greater learning and growth, and community benefits occurred (Tsamenyi et al., 2010) but it also stressed that privatisations should be evaluated against development criteria rather than via myopic macro-level and financial analyses. The latter plays an ideological and cultural role through an economically determinist discourse (Alam et al., 2004; Rahaman et al., 2004; 2007). For example, accounting disclosures by English goldmining companies in colonial Ghana helped legitimate extracting surplus value and repressive labour policies (Maltby \& Tsamenyi, 2010): accounting discourse surrounding Balanced Scorecard performance indicators used to benchmark UK and Chinese units of a MNC rendered globalisation practical (Cooper \& Ezzamel, 2013). A worry is that accounting discourses sustain neo-colonialism; for example, colonial control and accounting-maintained bonded labour relations in nineteenth-century colonial plantations in British Ceylon continue (Alawattage \& Wickramasinghe, 2009).

Globalisation alters relations between international capital and nation-states, which raises major questions about the regulation of corporations. Traditional theories of imperialism cannot adequately explain how MNCs, culturally grounded in but not 
geographically bound to one nation-state, can dominate the economic environment; and how international financial institutions beyond democratic control impose their preferred economic solutions and an elite-driven global order (Murphy, 2008). DCs are particularly vulnerable as they often lack the clout, expertise or resources - and even regulatory laws and institutions - to regulate MNCs (see Hopper et al., 2009). For example, US financial power, financialisation and global supply chains of Apple Inc. and Foxconn International Holdings drove down labour costs in China to the benefit of stockholders but not to society (Froud et al., 2014). Nevertheless, nation-states still have considerable power, functions and authority to effectively regulate MNCs, but their capacity to act is constrained by history, domestic concerns, and economic interests (Arnold \& Sikka, 2001).

MNCs can benefit DCs. If fairly regulated and taxed, they can provide resources, be models of good commercial practice, increase accounting capacity, and provide superior wages and benefits to SOEs or local businesses whose owners often lack capital to invest and reap short-run benefits,. For example, joint ventures between Northern MNCs and Chinese SOEs and private enterprises brought beneficial adoption of and experimentation with Northern accounting techniques (Firth, 1996; Zhou, 1988), despite political constraints (O’Connor et al., 2004; 2006). Privatisations bringing local rather than foreign ownership are not invariably more successful: locals can be venal capitalists too (Uddin \& Hopper, 2003).

Effective regulation entails the need for effective accounting systems. Transfer pricing remains a major concern globally and severely affects DC's capacity to regulate and tax MNCs. ${ }^{12}$ DCs are disadvantaged because their domestic tax and administrative controls may be inadequate; financial statements of indigenous and $\mathrm{MNC}$ affiliates are unavailable; and the costs of complying with OECD guidelines are high (Emmanuel, 2012). Relations between rich Northern states and MNCs have produced weak regulation, thereby enabling transfer pricing to be abstracted from the politics and economics of international capitalism since 1945 (Armstrong, 1998). Undoubtedly, many MNCs use transfer pricing to avoid taxes and facilitate capital movements at the expense of state tax authorities, shareholders and other stakeholders (Sikka \& Willmot, 2010). For example, Otusanya (2011) found that MNCs in the oil, gas, and manufacturing sectors of Nigeria use complex accounting structures that exploit legal ambiguities, tax havens and offshore financial centres to under-report profits and avoid tax. Formulating mutually beneficial transfer-pricing policies for Northern and Southern countries lies mainly with the OECD and UN, but OECD information-sharing

\footnotetext{
${ }^{12}$ The OECD estimates that $60 \%$ of world trade involves intra-group transactions of MNCs (Emmanuel, 2012).
} 
agreements between countries and tax havens have proven ineffective for Southern countries which have insufficient expertise to exert political influence. Emmanuel (2012) argued that they should devote less time to technical minutiae, which often spawns further loopholes for tax avoidance, and instead concentrate on achieving consensus on a transfer-pricing reform agenda and appoint a transnational regulator to regulate this and MNCs more generally. Sadly, this major accounting topic of global importance is neglected by accounting researchers.

Similarly, there is scant research $\mathrm{n}$ how regulatory institutions (e.g. financial reporting and corporate governance regulators, national procurement agencies, SECs, anti-corruption agencies, and national audit offices) in DCs impact upon governance, accounting and transparency, which are substantial parts of IMF/WB recommendations in their Report on the Observance of Standards and Codes. Their existence is often cited in international circles and included in governance indices measuring state enforcement of transparent accountability of public and private enterprises but many DCs' institutions are weakly constituted and not well funded, and consequently cannot regulate well-staffed and financially powerful companies and accounting firms. Gradually, they become another SOE driven by political imperatives, whilst appearing to 'regulate' in the eyes of international donors and funding institutions.

\subsection{Government accounting and the resurrection of the state}

Whilst transnational institutions' policies for DCs still emphasise private sector growth, attracting FDI, privatisations and contracting out government services, it has become recognised that only the state can provide many large-scale services - e.g. health and education - and is often the major source of domestic capital and feasible leadership, particularly for major infrastructure projects. This brought more pragmatic policies and more aid (mostly from the North) going directly into DCs' Treasuries; hence more effective government accounting systems to manage and allocate public resources are vital (Akakpo, 2009; Iyoha \& Oyerinde, 2010; Schiavo-Campo, 2009).

SAPs often reduced the number and pay of civil servants, thereby weakening state capacity but the WB Framework (2010) seeks to reverse this. It advocates increased local self-determination of programmes through improved education and training of government officials; implementing legal systems conducive to business development; and developing robust financial systems for micro credit organisations through to large corporations (Graham \& Annisette, 2012). Transparent budgeting and accounting have become cornerstones of international policy (e.g. The Paris Declaration, 2005; Accra Agenda for Action, 2008; Busan 
Partnership on Effective Development Participation, 2011) to improve decisions, local planning and control; reduce corruption and fiduciary risk; monitor the effectiveness of aid against development goals; and make funders more accountable to their constituencies (Fyson, 2012). However, although there may be agreement over the ends, achieving consensus over the means has been fraught with challenges. For example, in 2009, the Copenhagen Accord ${ }^{13}$ apparently pledged US $\$ 100$ billion annually to DCs to offset climate change but how to manage this locally and monitor progress has been beset with arguments. The fear is that many DCs' governments may adopt the necessary legal and implementation frameworks but not enact effective government accounting systems, e.g. in Nigeria (Iyoha \& Oyerinde, 2010).

The continued advocacy of the WB and the IMF for NPM in government departments seeks a shift from input and process accountability (bureaucracy, rules, regulations) to results (appraising civil servants against key performance indicators); granting local managers greater discretion over means (subject to budget constraints); tendering out services; reconstructing civil service organisations around programmes; and improved reporting, accountability and monitoring mechanisms (Awio et al., 2007). The belief is that seeing citizens as customers and introducing Northern internal auditing and accounting systems will reduce principal-agent conflicts that civil servants face, improve information for decisions on programmes, help evaluate bids for service contracts or state assets, improve accountability, lessen corruption, and thus increase economic growth.

Accounting has contributed to a discourse of 'economic necessity' and 'there is no alternative' disseminated by the WB (Saravanamuthu, 2004) but evidence that the improvements promised materialise and thence promote development is lacking (see Wynne \& Lawrence, 2012a): at best the results appear patchy (Andrews, 2012). For example, WB-sponsored reforms imposed on the Ghana Food Distribution Corporation only changed financial reporting practices: budgeting remained politicised, delayed, directionless and ineffective, and reporting to the monitoring agency produced no positive accountability and performance changes (Uddin \& Tsamenyi, 2005). Similarly, Alam et al. (2004) found state development bank reforms incorporating profit centres and an emphasis on accounting results undermined the primacy of the local culture and beneficiaries in loan decisions. Furthermore, commercialised loan and repayment policies in the Fijian Development Bank hit a legacy of colonisation and racial discrimination, and

\footnotetext{
${ }^{13}$ The Copenhagen Accord is an international agreement among 25 nations attending the UN Framework Convention on Climate Change Conference.
} 
proved alien to the communal indigenous culture. A WB education project in Latin America to implant accounting governance practices and discourses met slippage, accommodation and resistance (Neu et al., 2008). Lastly, accounting technologies and agents within an IMF SAP team seeking Nigerian banking reforms hit contextual challenges and accounting data became 'managed': its potential disciplinary power remained but the government lacked the desire to enact it (Neu et al., 2010).

From the late 1980s, integrated financial management information systems (IFMSs) and medium-term expenditure frameworks (MTEFs) were frequently recommended. MTEFs link policy, planning and practice, normally over three years, to achieve a balanced budget and shift resources to pro-poor activities. IFMSs seek to facilitate more flexible responses to macro-economic and cash flow changes; and increase the accountability, efficiency and effectiveness of programmes through decentralisation, effective controls and improved data quality. Both require an ability to forecast accurately; clear national policies; government commitment; comprehensive budgets; coding that links results to inputs; transparent, accountable and effective civil service capacity; reliable indicators; local acceptance and involvement; a realistic and incremental change process; reasonably rewarded public servants; and cheap and reliable information technology. These are often lacking in Southern countries. Moreover, incentives to incorporate 'best practice' can be perverse. There is little evidence that improving public financial management, often introduced at the behest of the North, brings DCs more aid. Sometimes local officials use accounting systems and practices instituted by foreign donors to manipulate information to bolster the image and performance of organisations, e.g. Tanzanian local government departments did so to enhance their legitimacy for greater eligibility to grants and funding (Goddard \& Mzenzi, 2015).

Despite efforts of external aid-givers (particularly Northern donor government departments and international NGOs) to standardise and pool reporting by DCs, they must be accountable to their electorate and follow domestic legislation. Moreover, funders often want quick results on specific tangible achievements to impress their constituents (e.g. schools built) whereas capacity-building is long-term, less tangible, multi-faceted, and incremental. Thus donors may prioritise risk-minimisation that reduces local discretion, adaptability, standardisation and integration of accounting systems contrary to stated policy objectives, leaving local officials to deal with many complex and conflicting accounting requirements, which has weakened local development of public financial management (and also in NGOs) (de Renzio, 2006). Moreover, foreign consultants on short contracts and unacquainted with local conditions can reduce the confidence of local managers and produce reforms not tailored to 
the local context and available resources. Inequities in experience, status and qualifications may prohibit locals from challenging foreign consultants at the specification, tendering and implementation stages of accounting projects. This inadvertently stifles local involvement and contributes to reforms that do not deliver the improvements promised (Wynne \& Lawrence, 2012b). For example, despite "billions of aid dollars, mountains of red tape, heavy burdens on local government staff, and literally centuries of full-time-equivalent technical expertise devoted to MTEF" results are disappointing (Schiavo-Campo, 2009, p.7); and in much of Africa IFMSs proved too complex for local needs and needed substantial customisation (Peterson, 2007).

Accounting language underpins discourses of globalisation policies. For example, it underpinned a modernisation agenda directed at changing citizen attitudes during pension reforms in Chile (Himick, 2009); loan agreements between the WB, the UN Development Agency and some Latin American governments incorporated financial and accounting discourses that were alien and meaningless to many in DCs, which eventually hindered the reforms (Neu et al., 2006; 2008; 2009); for example, accountability and transparency reforms advocated by the Inter-American Development Bank and UNDP officials in El Salvador raised loan beneficiaries' aspirations but, once implemented, the discourse and practices had to be changed because locals found they restricted their social space and contravened established practices (Neu et al., 2009).

Reformers seeking accounting and governance changes in DCs can meet tough resistance from domestic politicians. Reforms can have unanticipated and unintended consequences and become instruments that nullify their very aims (de Renzio, 2006). For example, the General Inspectorate of State in Benin - a key accounting institution reinstated within good governance reforms of the President - was used to persecute unions and other organisations (including civil society ones) demanding public investigations of financial scandals (Wynne, 2011). Similar cases were reported for anti-corruption institutions in Malawi - they were used to eliminate political rivals. Local politicians may lack commitment to accounting reforms that erode their power to siphon public funds from government treasuries and extract economic rents within a façade of rules (Cammack, 2007). For example, anti-corruption initiatives in Uganda threatening the regime's patronage-based support lacked political commitment (Robinson, 2006). The failure of IFMS in Ghana was attributed to politicians believing that it was a technical matter foisted on them, but their support waned when they realised the political implications of greater transparency and accountability (Wynne, 2005). In Tanzania, the government sought to benefit from the legitimacy associated with the 
activities of its supreme audit institution, the National Audit Office of Tanzania whilst simultaneously constraining its reach and influence, which subordinated auditors and produced contradictory public sector auditing practices (Goddard \& Malagila, 2015). In Benin, the Chamber of Accounts, the supreme audit institution, has never had the resources or independence needed to audit government accounts: it performs less than ten per cent of its constitutional mandate, allowing corruption and misappropriations across the government sector to thrive (Akakpo, 2009), and telecommunications reforms required no accounting making it difficult to trace where millions of US dollars were spent (Sutherland, 2011).

Development specialists often attribute such problems to neopatrimonialism (Le Vine, 1980; Roth, 1968) - a hybrid post-Weberian invention: "a creative mix of two Weberian types of domination: a traditional subtype, patrimonial domination, and rational-legal bureaucratic domination" (Erdmann \& Engel, 2007, p.104). Weber (1947) saw patrimonialism as a traditional and legitimate form of authority often found in small-scale, traditional, sometimes tribal societies where relations between rulers and subjects are not governed by predictable economic calculations and codified laws (Pitcher et al., 2009). Here rulers distribute symbolic and material rewards (often unevenly) to fulfil reciprocal obligations in a shared culture. Relations are direct, dyadic and personal with no delineation of private and public realms or formal mechanisms of accountability or transparency. Nevertheless, leaders are accountable within traditional collective codes (Pitcher et al., 2009).

Eisenstadt (1973), Médard (1983) and Clapham (1985) added the prefix 'neo' to distinguish contemporary patrimonialism from its traditional form. Here officials "hold positions in bureaucratic organizations with formally defined powers exercised, insofar as they can, not towards public service but as if they are private property" (Erdmann \& Engel, 2007, p. 48) and they personally distribute resources ('rents' in modern economic terminology) informally to further their interests (Kelsall, 2011). The distinction between private and public spheres formally exists and public reference is made to it, but in practice the distinction is blurred. Rational-legal formal rules define authority and responsibilities and provide legitimacy for seeming bureaucracies but, within them, patronage, clientelism, corruption, nepotism and ethnicity abound (Lemarchand \& Legg, 1972; Scott, 1969; Zolberg, 1969). The exercise of power in neo-patrimonial regimes is erratic and incalculable. It is (but not always) associated with corruption by rulers, i.e. Presidents, MPs, chiefs, party officials, and government bureaucrats.

Nevertheless, citizens, particularly rural villagers, may expect patrimony from local leaders. Elections may be rigged and are expensive for candidates, and political loyalties may 
split along ethnic, regional or religious lines. Given their scepticism of politics, politicians, and the state, and orientations to traditional patrimonial leadership, civil society is 'weak and silent' in many DCs (Cammack, 2007, p. 600). Indeed, democracy and multi-party elections can intensify neo-patrimonial governance (voters seek bribes and favours from candidates who then recoup their electoral costs from illicit raids on government resources). Goddard et al. (2015) uses Ekeh's (1975) concept of 'two publics' to explain persistent corrupt practices, weak accountability, and their impact on government accounting in Africa. Society is split between a highly amoral civic public with strong connections with Northern donors, and a primordial public with strong moral values but little expectation that civic public members will adhere to such values. Drawing on a Tanzania case, the nexus between these publics, particularly the civic public's lack of morality led "to opportunistic, lawless and corrupt tendencies" (ibid, p.15) and sustained unscrupulous accounting practices across the government sector. Reconciling accounting reforms to increase indigenous involvement, civil society involvement and broader development goals with national sovereignty and neopatrimonial governance is arguably the major accounting issue in DCs today, and by implication, it warrants greater research attention.

\subsection{Social and environmental accountability}

Following the international acceptance of the Millennium Development Goals, the onus of protecting DCs has increasingly fallen on the UN secretary-general, the WB president and the IMF's managing director, all proponents of globalisation (Cobham \& McNair, 2012). Accounting policies and practices should now be judged against HDI goals: stock market and economic measures that permeate accounting are woefully inadequate for the realms of civil society, ecology, politics, inequality, gender, health and education. However, the WB and IMF still judge DCs' accounting progress according to their adoption of 'Northern' marketbased accounting (Andrews, 2012). The presumption that appearing to conform to Northern systems denotes success is questionable given that actual conformity is often absent or that such accounting can produce dysfunctional and unanticipated consequences.

Globalisation and trade liberalisation have damaged the environment, giving rise to environmental activism and protests globally (Ritzer, 2007; Stiglitz, 2003). For example, the beef and soybean industries are primarily responsible for deforestation of the Amazon (Nepstad et al., 2006); in India, arguably an example of successful globalisation, environment degradation has had drastic consequences for the poor (Martens \& Raza, 2010); outsourcing production from the UK and Denmark to China increased its carbon footprint (Herrmann \& 
Hauschild, 2009); and global warming created partly by globalisation may increase temperatures by $1.5^{\circ} \mathrm{C}$ to $4.5^{\circ} \mathrm{C}$ in many areas, make others cooler, and alter rainfall regionally (Intergovernmental Panel on Climate Change, 1996). DCs are particularly vulnerable given their lack of resources to mitigate these consequences. Proponents of globalisation, such as the WTO, claim that its policies encourage environmental improvement but their statistical justifications may apply only where 'weak conditions' are satisfied, or when limited environment metrics are used (Hecht et al., 2006).

Corporate social responsibility (CSR) reporting in DCs has been under-researched (Belal \& Cooper, 2011) although work is emerging. ${ }^{14}$ CSR reporting practices have been observed in Thailand (Kuasirikun \& Sherer, 2004), Bangladesh (Islam \& Deegan, 2008); South Africa (De Villiers \& Van Staden, 2006; Soobaroyen \& Ntim, 2013), Ghana (Maltby \& Tsamenyi, 2010), and Mauritius (Mahadeo et al., 2011). Trends towards CSR may reflect changing stakeholder and societal attitudes (De Villiers \& Van Staden, 2006; Soobaroyen \& Ntim, 2013), and may mimic CSR developments in Northern countries, disseminated through material such as the Global Reporting Initiative and the Integrated Reporting Framework. CSR aims vary between countries; some are directed at foreign audiences - e.g. multinational buyers in Bangladesh, or funders in Ghana - whilst elsewhere local influence predominates e.g. South Africa. Most empirical work depicts CSR as a strategy for stakeholder management and maintaining organisational legitimacy. It questions whether globalised capitalism can engender social progress. For example, Bangladeshi corporations are unlikely to report on child labour practices, equal opportunities and poverty alleviation, given their lack of resources, their profit imperative, no legal requirements, absence of knowledge and awareness of the issues, and fears that reporting poor social performance would generate bad publicity. Fijian accountants were unwilling to engage in environmental accounting due to their lack of competence, its voluntary nature, and practical difficulties (Lodhia, 2003). Even when social and environmental reporting was a WB funding condition results can be disappointing; for example, in the Volta River Authority in Ghana, and Delco in Sierra Leone, it masked transnational capital penetration and exploitation (Rahaman et al., 2004; Tinker, 1980).

Changing development policies raise new accounting issues, such as human rights ${ }^{15}$ (see Lauwo \& Otusanya, 2014). However, its emergence within CSR discourse has critics

\footnotetext{
${ }^{14}$ For example, see the Accounting Forum Special Issue on reporting in emerging and developing economies (Vol. 37, No. 2, 2013).

${ }^{15}$ Refer to the special issue on human rights in Critical Perspectives on Accounting (2011, V.22, N.8)
} 
(McPhail \& McKernan, 2011). Some see it as a triumph of modernity (Douzinas, 2000), critical legal scholars question whether it pursues class and gender interests (Dembour, 2006), and others dismiss it as postmodern cynicism when so many people are subjugated, starved, or exterminated (Douzinas, 2000; 2007). Sikka (2011) claims that accounting has not responded to this agenda, except for some MNCs that use stabilisation clauses to constrain a host country's ability to protect and enhance human rights, as in the Chad-Cameroon oil and pipeline project. He puts greater faith in counter accounts that challenge the hegemony of corporations whilst Lauwo and Otusanya (2014) advocate board and governance reforms to ensure greater corporate accountability and commitment to human rights. However, the situation is not entirely bleak. Accounting and social disclosure contributed to South African divestment debates in the USA during the 1970s and 1980s (Arnold \& Hammond, 1994). In 2011 the UN Human Rights Council endorsed Guiding Principles on Business and Human Rights and some corporations have incorporated this, such as TNT and AngloGold Ashanti. Eighteen major global clothing and retail companies from 1990 to 2007 made significant disclosures according to the International Labour Organisation's (ILO) workplace human rights standards (Islam \& McPhail, 2011). In this context, corporate developments may be outstripping academic research here (Gray \& Gray, 2011). The WB and IMF, like aid departments of Northern governments, struggle to reconcile their commitment to Millennium Development Goals, good governance, and adopting social indicators with a neo-liberal Northern accounting hegemony. Whether they are reconcilable is questionable and lies at the heart of social and environmental accounting research (Molisa et al., 2012).

\subsection{The Rise of Non-governmental Organisations: Accountability to Whom? ${ }^{16}$}

A by-product of changing development policies has been the rise of NGOs, some of which (e.g. BRAC and AXA in Bangladesh) now resemble international conglomerates. Defining NGOs is difficult: they are not new, they vary in size, and many are not involved in development. However, since the 1980s, NGOs have become major agents in development. NGOs are no longer perceived as small bands of activists but rather as new 'super brands' serving consumers who grant them more esteem than major corporations, government bodies and even the media (Wootliff \& Deri, 2001).

The 'boom' period for NGOs is related to structural transformations in capitalism; namely macro-economic instability in many DCs and shifts to formally liberal democracies

\footnotetext{
${ }^{16}$ This section draws considerably from Ahmed and Hopper (2015).
} 
and civil society participation (Mitlin et al., 2007). NGOs appeal across the political spectrum (Clarke, 1998). Some have transcended financial, operational and ideological barriers to become viewed by governments and corporations as potent political forces (Gray et al., 2006; Unerman \& O’Dwyer, 2006a). For liberals, NGOs help to balance state and business interests and prevent them from abusing their power (Lewis, 2001). For neo-liberals, NGOs are private sector institutions that encourage market behaviour such as through micro-credit, entrepreneurship training, and private 'not-for-profit' actions. For the left, NGOs promise a 'new politics' of social transformation with an alternative radical strategy for capturing state power and overcoming centralisation. Subsequently, NGOs can mean all things to all people (Clarke, 1998; Gray et al., 2006; Mitlin et al., 2007).

The WB classifies NGOs into two main categories. ${ }^{17}$ Operational NGOs design and implement projects in areas such as disaster relief, health care, education, housing, legal provision, and micro-credit. Advocacy NGOs defend or promote a cause and influence policies and practices, particularly alleviating poverty by promoting equity, citizen participation, expanding rural employment and income, and fostering democratic organisations such as farmers' associations and co-operatives. The operational and advocacy categories are not mutually exclusive - many NGOs engage in both.

Many NGOs have responded to changing development policies and promulgate market forces alongside good governance (Howell, 2002). Northern governments' linking of aid to political reform, and placing more funding directly into DCs' government coffers has lessened external funding for operational services (Fisher, 1998). Thus many NGOs have switched from delivering welfare services to providing micro-credit and advocacy of greater democracy, often on Northern models, and campaigning over environmental, gender, civil society accountability, and social development issues (Pearce, 2006; Unerman \& Bennet, 2004; Unerman \& O’Dwyer, 2010). NGOs offer Northern funders the means to engage with a wider spectrum of civil interest groups (Mercer, 2002) and they have succeeded in gaining access to policy makers and getting their ideas implemented through activism, campaigning and policy dialogue (Clarke, 1998).

Support for NGOs stems from their alleged proximity to remote communities and the poor (Awio et al., 2011); efficient low-cost operations, e.g. micro-credit programmes (Hulme \& Moore, 2007); promotion of sustainable development (O’Dwyer \& Unerman, 2007); and their potential for organising and representing civil society (Devine, 2006; Gray et al., 2006;

\footnotetext{
${ }^{17}$ See World Bank report "NGO World Bank Collaboration" published in www.worldbank.org.
} 
Lehman, 2007). Nevertheless, NGOs are not universally acclaimed. They have been accused of being 'Janus-like' organisations exhibiting 'mushroom growth' (Turner \& Hulme, 1997); continuing the missionary tradition and being handmaidens of capitalist change (Temple, 1997); showing scanty evidence of superior long-term performance (1993; Vivian \& Maseko, 1994); being resource brokers rather than change agents (Pearce, 2006); providing palliatives to poverty rather than precipitating significant structural change (Tembo, 2003; Wright, 2012); serving so many of the divergent vested interests that fundamental development problems are denied (Rahmani, 2012; Wright, 2012); and drifting from their original mission and even into financial corruption (Gibelman \& Gelman, 2004; Townsend \& Townsend, 2004). Independent information on NGOs' practices and whether beliefs underpinning their rapid growth are justified is lacking (Jordan \& Van Tuij1, 2000). Some commentators remain suspicious of claims that NGOs represent civil society and promote democratic development, arguing that their legitimacy owes more to ideology and unproven assumptions of dominant institutions rather than to wider political development debates (Gray et al., 2006; Lehman, 2007; Rahmani, 2012).

Tensions between neo-liberal economic policies, broader development goals and good-governance policies are exemplified in debates about micro-finance. Roy (2010) delineates a 'Washington' - i.e. WB and IMF - approach to micro-finance that renders poverty alleviation an economic problem caused by the poor's lack of access to capital for entrepreneurial ventures, best rendered by commercial institutions. She contrasts this with the 'Bangladesh' approach pioneered by NGOs such as Grameen whereby lending is linked to education and training of loan recipients on business skills - but also to empower them socially and politically. Roy (2010) fears that the market-led approaches reduce the poor and marginalised to economic subjects and ignores development issues such as increasing civil society influence upon politics. Jacobs et al. (2012) express similar fears, arguing that microfinance's accounting can be an instrument of oppression and exploitation, rendering the poor the financiers of poverty alleviation.

The structures within which NGOs operate, particularly international ones, creates an inherent accountability problem. Edwards and Hulme (1995, p. 224) state that they "are accountable to trustees in one country but working with communities in others; committed to fundamental reforms but funded by donors and supporters who (by and large) demand short term results". If their accountability fails to reproduce their mission aims they appear hypocritical. The concern is that adopting conventional accounting may deflect their (NGOs') accountability from their fundamental values, missions and obligations to grassroots clients 
(Gray et al., 2006). Unerman and O'Dwyer (2012) trace four forms of NGO accountability: identity, upward and downward, and holistic. Identity accountability is confined to a few NGOs with members strongly committed to their moral ends. Holistic accountability incorporates broader social, environmental and economic factors - the basis of many NGOs' missions. Given shifts to good-governance policies, social and environmental accounting systems are no longer esoteric fantasies but lie at the heart of contemporary development. Upward accountability is primarily to donors; it uses conventional financial accounts and narratives to monitor whether resources were spent as planned and efficiently. Downward accountability entails dialogue with clients so they can influence NGO activities in the spirit of empowerment and involvement.

There are tensions in reconciling upward (formal) and downward (informal) accountability. Upward accountability mechanisms can overemphasise short-term quantitative targets and favour hierarchical management structures, resulting in ".. 'accountancy' rather than accountability" (Edwards \& Hulme, 1996, p. 968) that only measures the easily measurable, neglects less tangible social and political goals, and does not reflect the longer-run effectiveness of aid. For example, three Tanzanian NGOs with formal, structured and adequately staffed systems were not perceived as more accountable (Goddard \& Assad, 2006, p.397); and, when a microfinance NGO in Zambia undergoing crisis and fraud improved its upward accountability, it detracted from the vital reliance upon and trust needed amongst borrowing groups and loan officers (Dixon et al., 2006). However, NGOs are not immune from corruption, mismanagement, mission drift, and capture by powerful interest groups and funders; and NGO legislation and regulation is inadequate in many DCs, hence the need for upward accountability.

NGOs are caught in a dilemma. Pressing demands of upward accountability to donors, and adoption of hierarchical management controls following NGOs' growing scale and scope, can impede the downward accountability many seek. For example, the Red Cross, the Humanitarian Accountability Partnership and the Sphere Project jeopardised their humanitarian and moral goals by adhering to scripts emphasising neutrality, commerce, and performance (Everett and Friesen, 2010); an Irish aid organisation struggled to reconcile greater accountability demands with its social goals, particularly empowerment of clients (O'Dwyer, 2005); the Irish section of Amnesty International feared that their reliance on internal accountability, augmented with ad hoc external accountability mechanisms, had stymied managers' preference for holistic accountability to a wide range of stakeholders, privileged a narrow range of (potentially) powerful stakeholders, and was counterproductive 
to its mission (O'Dwyer and Unerman, 2008); and neo-liberal "development accounting" designed to empower the rural poor in a Sri Lankan village actually disempowered them due to local politics and patronage (Jayasinghe \& Wickramasinghe, 2011).

Accountability to clients is crucial, as many NGO officers are unelected, and NGOs can become vehicles for ideology (Lehman, 2007). Mindful of such dangers, some donors and funders advocate beneficiary involvement. However, actual accountability and 'textbook' notions of downward accountability proclaimed by NGO chiefs can diverge: it can be tokenistic and not lead to changes in core development ideals and attitudes (O'Dwyer \& Unerman, 2010). Moreover, its formalisation may corrupt well-meaning intentions of those demanding downward accountability, leading to ambiguity and misplaced priorities amongst NGOs' staff (Dixon et al., 2006). Given that clients are often illiterate, and are not habituated to participation or exercising their human rights, this often requires verbal and imaginative means of downward accountability, otherwise it may merely serve to legitimate the process of downward accountability (Goddard \& Assad, 2006).

Development studies researchers express concerns about how a fixation with accountability may deflect NGOs from their objectives and ideals (Van Ufford et al., 2003) but few explore the role of accounting practices and techniques therein. There is a need for accounting researchers to delve further into how NGOs can best design and enact accounting systems that reproduce and monitor broader development aims whilst satisfying the demands of Northern funders.

\section{Discussion and conclusions}

Whilst many studies of accounting, globalisation and development remain a-theoretical (van Helden \&Uddin, 2016), many others use a wide range of theories, ${ }^{18}$ explicitly or implicitly, often from institutional theory and political economy (e.g. Iyoha \& Oyerinde, 2010; Schiavo-Campo, 2009). This reflects the social, political and cultural turn of much accounting research over the last three decades, and its extension to conceptualise how the dynamics of globalisation and its accounting, play out in DCs (Alawattage et al., 2015).

\footnotetext{
${ }^{18}$ They include institutional theory (e.g. Arnold, 2005; Covaleski et al., 2003; Firth, 1996; Mir \& Rahaman, 2005; Rahaman et al., 2004), Foucault (governmentality) (e.g. Everett et al., 2007; Lehman, 2005; Neu \& Heincke, 2004), legitimacy and stakeholder theory (e.g. Islam \& Deegan, 2008; Soobaroyen \& Ntim, 2013), Weber and notions of rationality (e.g. Dyball \& Valcrcel, 1999; Uddin, 2009), structuration theory (e.g. Jayasinghe \& Thomas, 2009; Uddin \& Tsamenyi, 2005), political hegemony (e.g. Alawattage \& Wickramasinghe, 2008; Yee, 2009; 2012), political economy (e.g. Armstrong, 1998; Belal \&Cooper, 2011; Lassou \& Hopper, 2015; Wickramasinghe \& Hopper, 2005), concepts of imperialism (e.g. Annisette \& Neu, 2004; Chua \& Poullaos, 2002; Catchpowle and Cooper, 1999), and labour process and professionalisation theories (e.g. social closure) (e.g. Hamond et al., 2009, 2012; Sian, 2011; Uche, 2002; Uddin \& Hopper, 2001).
} 
Many of these studies critique mainstream macro-economic development perspectives after discovering that accounting premised on economic assumptions is mediated by socio-political and cultural factors, with positive and negative, and intended or unintended, consequences. Weber's delineation of tradition versus 'rational-legal' bureaucracy in modern society has been widely used to explain how accounting reforms have unintended consequences in societies that do not share the underlying assumptions of such reforms. Overall, there is greater recognition of the need to afford greater voice to indigenous actors - but how to do so remains problematic. This has spurred deeper theorisation of how societal dynamics involving factors such as race, ethnicity, culture, religion, colonial history, political emancipation and politics impinge on mainstream accounting and accountability. For example, Hopper et al. (2009) use a cultural-political economy approach to identify how factors ${ }^{19}$ in five different economic and political regimes in many DCs shaped management accounting. Alawattage et al. (2015) call for greater epistemic theorisation of global pressures for accounting change and of how decision-makers in DCs perceive and translate these changes and its implications for how accounting reforms are communicated, deployed and used (if at all) locally. However, further theorisations critically examining how accounting impacts upon local economies, communities, the disadvantaged, and ensuing resistance are emerging: e.g. Bourdieu (Alawattage, 2011); actor-network theory (How and Alawattage, 2012); Habermas' theory of communicative action (Kuasirikun, 2011); globalisation theories (the global-local dialectic) (Barrett et al., 2005).

A recurring finding is that accounting knowledge and practices in DCs are driven by 'international accounting institutions' such as the IASB and IFAC, with the WB, IMF and UN acting as mediating agents, and large Northern (often the 'Big 4') accounting consultants delivering the technical detail. Together they reproduce Northern systems and ideology in private and public sectors alike and often further Northern commercial interests, not least in financial services, where the 'Big 4' accounting firms and Northern accounting associations seek global expansion. Much aid is channelled back to donor countries through fees, and procurement of technology and equipment from Northern suppliers (Chang, 2007; SchiavoCampo, 2009). This is aided by the WB gauging DCs' accounting and profession solely against international accounting and auditing standards and often concluding they are inadequate, e.g. ROSC exercises for Morocco in 2002, and for Nigeria in 2004. Admittedly, some local accounting practices and professions have been found to be linked to unethical

\footnotetext{
${ }^{19}$ The factors were mode of production; culture, ethnicity and race; the state, regulation and law; political parties; industrial relations, and 'globalisation dynamics' pertaining to international finance.
} 
behaviours and thereby discredited by association (Lassou at al., 2014). A further frequent observation is the asymmetry of power between Northern and Southern governments, professional associations, MNCs, and transnational accounting and auditing standard setters. Sadly, attempts of global accounting regulators to redress this have lacked scale and substance: this is a practical but also a moral issue, as many DCs lack the resources, expertise, and sometimes the leadership to influence global accounting principles and practices. Many transnational accounting organisations fail to recognise this: DCs are under-represented within IFAC and particularly the IASB; and the IASB has shown little willingness to countenance challenges to their authority and legitimacy.

Northern accounting associations are major purveyors of accounting knowledge and credentialing of accountants across DCs. Despite their potential to help DCs increase their accounting capacity, their activities are often problematic. Many DCs established their own tertiary and other indigenous educational institutions, and professional associations, which were often under-resourced and lack expertise; accordingly they aligned themselves with Northern associations (e.g. as approved learning partners) and Northern higher education institutions to gain international recognition (Bennell \& Pearce, 2003; Yapa, 2006). There are reports of successful collaboration but this carries dangers. Often, indigenous accountants learn Northern accounting rules/principles to the detriment of local ones, and problems of applying Northern accounting technologies to local conditions are ignored. Moreover, it divides Northern credentialed accountants, often employed by large Northern accounting firms serving resident MNCs or MNCs themselves, from local association members. Ensuing conflicts feed beliefs that local accounting standards/rules and accounting professions are weak and below expected standards, and weaken DC governments' attempts to cultivate local accounting capacity, strengthen local associations, and provide the necessary legislation and infrastructure. Unfortunately, we know little about how and why Northern professional associations embark on and formulate their globalisation policies; their alliances and relations with domestic associations and tertiary education institutions; whether policies, syllabi and practices vary across associations and country collaborations; whether indigenous governments and other local constituencies support their activities; and whether they strengthen local accounting capacity - not least in financial service markets.

In looking forward it is important to also look back. A deeper understanding of globalisation of accounting may emerge from studies drawing on national archives or archives of large MNCs. Such sources have revealed how accounting was implicated in the exploitation, expropriation, and extermination of original populations in settler and non- 
settler colonies; and the troubled development of their national professions. Historical work can bring new insights that challenge our knowledge of accounting functions and operations in DCs and offera better understanding of context to inform contemporary solutions.

The rise of powerful new global players such as China, India, Russia and South Africa from non-Northern countries, and global alliances, may change Northern dominance, e.g. China has a growing commercial and cultural presence across Africa ${ }^{20}-$ its investments grew from US\$1.57 billion in 2007 to US\$5.49 in $2009 .^{21}$ It is heavily involved in infrastructure and educational projects. Yet we know little about their activities or their effect in the accounting arena. How do they manage their operations in DCs? How do their accounting systems and practices travel to other DCs? Are they drawn from Northern or home-country approaches? Do they accommodate the requirements, culture, and accounting systems and practices in the host country, or do they reproduce hegemonic and neo-colonial tendencies like their Northern counterparts?

It is, however, problematic to assume that transnational organisations constitute a homogenous whole and pursue a unitary goal. We know little about their internal dynamics, their inter-relationships, and their outcomes. Recent reviews (e.g. Alawattage et al., 2016; van Helden \& Uddin, 2016) recognise the importance of the discourses of 'globalising agents' but insights from WB and IMF actors are scarce. For example, at the UN and G20 summits, the WB and IMF criticised international accounting regulators for neglecting DCs, and urged global alliances of professional accounting associations to include more members from DCs. The WB is a large bureaucracy with various departments dealing with accounting issues and its field officers are scattered globally. It now has more accountants engaged in policy and advice but accounting researchers know little about their work and have little interaction with them. Their work may contain multiple agendas, interests and ideologies susceptible to different geopolitical and regional realities and approaches. For example, within the WB, the regional representatives for Francophone Africa are often French and trained or worked in the French administrative system. French geopolitical interests in Francophone Africa are more formally and elaborately structured than in former British African colonies (Joseph, 1976; Lassou, 2014; Martin, 1995). Similarly, in the IMF, the advisor for AFRITAC (the Regional Centre of Technical Assistance for West Africa) ${ }^{22}$ is a former French official from the French

\footnotetext{
${ }^{20}$ See: http://www.focac.org/eng/zfgx/jmhz/ [Accessed Friday 04 September 2015].

${ }^{21}$ These figures may be under-reported and China also provides substantial loan financing to Africa, mainly commodity-backed (e.g. by oil and minerals) (Sun, 2014).

${ }^{22}$ This covers Benin, Burkina Faso, Ivory Coast, Mali, Mauritania, Niger, Guinea, Bissau Guinea, Senegal, and Togo.
} 
Ministry of Cooperation. Could this produce different policy orientations for ex-French colonies to once British ones? There is little research on how accounting policies and policymaking, so important for DCs, are formulated in transnational institutions: and by whom? What are the internal conflicts and debates, whose advice is sought, and why?

Critical accounting scholars need to engage with global financial and development institutions such as the WB and IMF to investigate how differing globalisation tendencies are represented and how they involve accounting, and to formulate effective but tailored solutions for DCs. Relevant accounting research is rarely presented in development journals and conferences. Accounting researchers' lack of interaction with officials in transnational institutions involved in accounting is surprising, particularly as they tend to be transparent and open and interactions with development economists are commonplace. Accounting researchers need to move beyond traditional means of knowledge diffusion to make an impact.

Although market-based accounting still dominates their accounting prescriptions for DCs, world leaders' commitment to Millennium Goals and good governance creates space for alternative accountings pertinent to Northern and Southern societies alike; e.g. CSR accounting, downward accountability and civil society involvement, human rights accounting, and the promotion of democracy (Lehman, 2005). Public participation in budget movements in DCs has brought experimentation in grass roots involvement in projects and local governance. Increasing beneficiary and civil society involvement may require unorthodox, informal controls across a wide range of social criteria to resist the economic reductionism of conventional accounting. Transparent and open accounting available to civil society organisations that monitor and report on government spending and an independent media may be more productive than internal controls that check compliance with externally prescribed accounting practices.

Nevertheless, in the midst of the excitement this generates, it is important to remember that conventional accounting is still advocated for effective governance and development, and plays an important role in planning, decision making, control and accountability, while matters like greater transparency, broader disclosure and improved transfer-pricing regulations are relevant to development goals. Whether some accounting that furthers broader development goals and good governance can be reconciled with conventional accounting remains an open issue. For example, NGOs endeavouring to meet donors' requirements and to manage their often large and complex organisations have increasingly adopted conventional Northern accounting, at possible cost to their humanitarian missions, beneficiary involvement and advocacy of political change. More work is required here, including whether this is practical 
and desired by beneficiaries and civil society, and whether - and if so, how - it can be meshed with local cultures and beliefs. Like issues raised by advocacy NGOs and CSR researchers they are essential not just for pressing practical reasons but also because they are fundamental to human rights and morality.

Governments and NGOs signed up to achieving ecological and social goals have hit problems measuring and weighting them, particularly in the longer run, less tangible ends such as civil society involvement embracing pluralistic dialogue. Should they be criteria when granting and monitoring funding? Who will do the measurements? What regulation is needed and will it be effective? Transnational financial institutions may be the least objective and neutral actors for this (Harrison, 2004). How will inequities of power and risk be recognised and will the burden fall mainly on DCs and the poor? Many DCs lack the legal and regulatory structures and resources for such exercises and they may formally accept such ends but not enact or manipulate them. If this is the case, should transnational institutions intervene and, if so, does this warrant external intervention into domestic politics? Such interventions are not new - transnational organisations already produce and reproduce a particular hegemony. Whatever the case, an alternative hegemony must replace international harmonisation of accounting based on a neo-liberal economic conceptual framework biased towards Northern interests. This may require thinking outside the box: a more critical conception of 'accountability' based on post-modern and post-structural accounting models may be needed (Lehman, 2005; 2009).

This paper catalogues a litany of failed or disappointing accounting reforms in DCs in the face of globalisation. Reforms are often implemented but prove irrelevant or unsuitable for local circumstances and needs, and become ceremonial, unused, or used for unintended purposes, and even be dysfunctional. A frequent recommendation is to grant greater ownership and influence to DC governments, civil servants, managers, beneficiaries and civil society to draw on local knowledge more, put basic support requirements in place, and instigate a better sequence of reforms. However, parties within DCs may not have congruent interests. Governments and businesses may not welcome transparency, or media and civil society scrutiny. Reforms must accommodate the indigenous political rationality, the national context, involve civil society; and avoid simply imposing Northern assumptions and practices that create mutually exclusive solutions: e.g. the state versus markets, state centralisation versus decentralisation to local organisations; civil society versus the body politic. More progress may come if applying foreign political logics is avoided; for instance, beliefs about legitimate governance and democracy may differ greatly in many DCs than in the North. Ideally, reforms 
should be based on knowledge of what accounting systems are effective, why, and how. This requires more grounded, processual and collaborative action research with locals to better link accounting to local circumstances and beliefs. Whilst accounting reforms and other technologies in the North are admittedly not devoid of criticism (Everett et al., 2007; Sikka, 2008), what is problematic in the case of DCs is the extent to which technologies may be contributing to significant issues affecting health, education, poverty, food supply and other socio-economic 'necessities'. Similarly to Northern countries, these reforms do not operate satisfactorily and 'muddle along', but crucially, their implications and consequences are far reaching. Furthermore, institutional safeguards in Northern countries (relatively independent regulators, effective judiciary recourse, civil society and press activism) may mitigate some of these consequences more effectively than in DCs.

In states with non-developmental characteristics, ${ }^{23}$ accounting reforms may achieve little without political change: but not all forms of neo-patrimonialism preclude economic development (Hopper, 2016). Local projects can benefit from leadership and coordination from benign neo-patrimonial leaders oriented to fostering longer-run attributes of developmental states. Accounting reformers must recognise political contexts: i.e. how are decisions made and in whose interests? Why do formal accounting mechanisms remain so weak? Where do the networks of power reside? What logic drives policy? How is bureaucracy maintained and used? Are traditions a factor; and how are elections won? Accounting reforms that fail to consider their political and cultural feasibility and realistic means of implementation may prove useless. In so doing it is important to distinguish political leaders from public servants. A powerful, stable, competent and insulated bureaucracy may exist or can be nurtured with the authority to create, direct and manage development; and be sufficiently competent, professional and autonomous to resist tests of political loyalty, even in many neo-patrimonial regimes.

It is wrong to lay corruption problems just at the doors of DCs. Many have corruption, patronage and clientelism levels similar to or lower than Northern countries when at similar stages of development (Hopper, 2016). Major anticorruption organisations (particularly the WB, UN, IMF, OECD, and Transparency International) portray it as a noble cause rectifiable through accounting technologies such as IFMSs, developing more professional accountants, adopting and applying IASs, and enacting a strong legal framework to support modern accounting practices. This presumes that corruption causes poverty but causality may flow in

\footnotetext{
${ }^{23}$ Development characteristics include strong central state authority and systems; political stability; all classes being taxable; regulated and disciplined labour; protection of the poor; a sense of nation and nationalism; and attracting domestic and foreign capital that promotes national development goals.
} 
the opposite direction (Everett, 2012). Neo-liberalism is just as conducive to corruption and whether poor governance is a cause or product of poverty is debatable. Development economists argue that increasing trade and markets to raise income levels will bring improved governance, and are sceptical of claims that neopatrimonialism impedes development. If this is the case, promoting conventional accounting reforms in DCs that serve economic ends have merit. However, other development experts argue that poor governance hinders development, which is not merely an economic phenomenon, hence the need for alternative accountings in areas like CSR and civil society involvement (Hopper, 2016). This debate within development studies is highly pertinent to determining the best shape of accounting reforms in DCs.

Accounting and financial reform to aid development does not stop at the doors of poor countries. Globalisation has precipitated a "race-to-the-bottom" between nations seeking to provide off-shore centres to the advantage of major businesses. Major accounting firms and a network of advisers play a key role here (Sikka, 2008). The opaqueness of many MNCs' finances is partly attributable to policies and practices in rich countries, particularly the deregulation policies of the last three decades. However, financial secrecy contributes to global market instability to the detriment of rich and poor countries alike but the loss in DCs can be immense. Illicit flows from DCs attributable to manipulation of cross-border invoices, non-arm's length pricing, financial secrecy - particularly in offshore financial centres, and a general lack of financial transparency have weakened DCs' economies to the benefit of richer countries (Cobham \& McNair, 2012). The losses could finance development and outstrip current aid; losses also weaken governance, and promote corruption and poor governance. Moreover, Northern accounting (and accountants) and transnational institutions give an ambivalent message about accounting's role: it is deemed unproblematic and a de facto part of the solution but it can enable as well as constrain corrupt practices (Everett et al., 2007). For example, the Bush Administration's neo-liberal agenda in Iraq created a corrupt, lawless environment where corporations could reap huge profits through malfeasance. Audit reports from the Office of the Special Inspector General for Iraq Reconstruction suggested that laissez-faire policies were innocent mistakes and that failures were independent of one another, and it reconstructed corporate malfeasance as waste, whilst criminalising low-level employees, and blaming government agencies, the war and Iraqis for fraudulent activities (Chwastiak, 2013).

Northern academic researchers also have a responsibility to DCs. Governments and academics in DCs, in their desire to gain funding and status (whether for research, capacity- 
building, development or student recruitment), often mirror research policies of Northern institutions (Altbach \& Knight, 2007; Marginson, 2006). For instance, journal rankings such as the ABS (UK Association of Business Schools), the ABDC (Australian Business Dean Councils) and the FNEGE (French Fondation Nationale pour l'Enseignement de la Gestion de l'Entreprise) have 'travelled' to DCs and their business schools rely on these for appraisal and promotion purposes (Altbach, 2004). This can lead academics to align themselves with research approaches and themes that are peripheral if not irrelevant to development priorities of DCs. For example, academics in many Asian economies are incentivised to publish in highly ranked US-based journals and consequently they often use US data to enhance their publication chances. Even when local academics use local data they must still meet institutional pressures to publish in highly ranked international accounting (primarily Northern) journals (Gul et al., 2013; Teoh \& Zhang, 2011) that can be ignorant or unsympathetic to research issues and problems in DCs. Given the scarcity of accounting researchers in DCs, this wastes an important resource. Moreover, English has become the dominant if not unique language of research worldwide (Komori, 2015; Marginson, 2006) which denies access to non-English speaking scholars, reinforces Anglophone orientations, and deflects attention from work in indigenous languages or that of former colonisers: assistance with translation remains a neglected but important issue.

\section{References}

Accra Agenda for Action, (2008). Third High Level Forum on Aid Effectiveness. Accra: Ghana.

Agrizzi, D., \& Sian. S. (2015). Artificial corporatism: A portal to power for accountants in Brazil. Critical Perspectives on Accounting, 27, 56-72.

Aizenman, J., \& Jinjarak. Y. (2009). Globalisation and Developing Countries - A Shrinking Tax Base? Journal Development Studies, 45(5), 653-671.

Ahmed, Z., \& Hopper, T. (2015). Politics, Development and NGO Accountability. In Z. Hoque, \& L. Parker (Eds.), Performance management in non-profit organizations: global perspectives. Oxford: Routledge.

Akakpo, M. B. (2009). Réflexions sur la Gouvernance Financière au Bénin. Cotonou: Transparency International-Bénin.

Alam, M. (1997). Budgetary process in uncertain contexts: a study of state owned enterprises in Bangladesh. Management Accounting Research, 8(2), 147-67.

Alam, M., Lawrence, S., \& Nandan, R. (2004). Accounting for economic development in the context of post-colonialism: the Fijian experience. Critical Perspectives on Accounting, 15(1), 135-157. 
Alawattage, C., \& Wickramasinghe, D. (2009). Institutionalisation of control and accounting for bonded labour in colonial plantations: A historical analysis. Critical Perspectives on Accounting, 20(6), 701-715.

Alawattage, C., Wickramasinghe, D., \& Uddin, S. (2016). Theorising management accounting practices in Less Developed Countries in Harris E. (eds). The Routledge Companion to Performance Management and Control, forthcoming.

Altbach, P. G. (2004). Globalisation and the university: Myths and realities in an unequal world. Tertiary Education and Management, 10(1), 3-25.

Altbach P.G., \& Knight J. (2007). The Internationalization of Higher Education: Motivations and Realities. Journal of Studies in International Education, 11: 290-305.

Andrews, M. (2012). The Logical Limits of Best Practice Administrative Solutions in Developing Countries. Public Administration and Development, 32(2), 137-153.

Andrews. M. (2013). The Limits of Institutional Reform in Development - Changing the Rules for Realistic Solutions. New York: Cambridge University Press.

Annisette, M. (2000). Imperialism and the professions: the education and certification of accountants in Trinidad and Tobago. Accounting, Organizations and Society, 25(7), 631-659.

Annisette, M. (2003). The colour of accountancy: examining the salience of race in a professionalisation project. Accounting, Organizations and Society, 28(7-8), 639-674.

Annisette, M. (2004). The true nature of the World Bank. Critical Perspectives on Accounting, 15(3), 303-323.

Annisette, M, \& Neu, D. (2004). Accounting and empire: an introduction. Critical Perspectives on Accounting, 15(1), 1-4.

Armstrong, M.A. (1998). The political economy of international transfer pricing, 1945-1994: State, capital and the decomposition of class. Critical Perspectives on Accounting, 9(4), 391-432.

Arnold, P.J. (2005). Disciplining domestic regulation: the World Trade Organization and the market for professional services. Accounting, Organizations and Society, 30(4), 299-330.

Arnold, P., \& Hammond, T. (1994). The role of accounting in ideological conflict: Lessons from the South African divestment movement, Accounting, Organizations and Society, 19(2): 111-126.

Arnold P.J. \& Sikka P. (2001). Globalization and the state-profession relationship: the case the Bank of Credit and Commerce International, Accounting, Organizations and Society, 26(6): 475-499.

Asechemie, D. P. S. (1997). African labour systems, maintenance accounting and agency theory. Critical Perspectives on Accounting; 8(4), 293-410.

Awio, G., Lawrence, S. R., \& Northcott, N. (2007). Community-led initiatives: Reforms for better accountability? Journal of Accounting and Organizational Change, 3(3), 209-226.

Awio, G., Northcott, D., \& Lawrence, S. (2011). Social capital and accountability in grass-roots NGOs: The case of the Ugandan community-led HIV/AIDS initiative. Accounting, Auditing \& Accountability Journal, 24(1), 63-92.

Bakre, O. M. (2006). Second attempt at localising imperial accountancy: The case of the Institute of Chartered Accountants of Jamaica (ICAJ) (1970s-1980s), Critical Perspectives on Accounting, 17(1), $1-28$. 
Bakre, O. M. (2008). Financial reporting as technology that supports and sustains imperial expansion, maintenance and control in the colonial and post-colonial globalisation: The case of the Jamaican economy. Critical Perspectives on Accounting, 19(4), 487-522.

Bakre, O. M. (2014). Imperialism and the integration of accountancy in the Commonwealth Caribbean. Critical Perspectives on Accounting, 25(7), 558-575.

Baker, C. R., Biond, Y., \& Zhang, O. (2010). Disharmony in international accounting standards setting: The Chinese approach to accounting for business combinations. Critical Perspectives on Accounting, 21(2), 107-117.

Barrett, M., Cooper, D. J., \& Jamal, K. (2005). Globalization and the coordinating of work in multinational audits. Accounting, Organizations and Society, 30(1), 1-24.

Belal, A. R., \& Cooper, S. (2011). The absence of corporate social responsibility reporting in Bangladesh. Critical Perspectives on Accounting, 22(7), 654-667.

Bennell, P., \& Pearce, T. (2003). The internationalisation of higher education: exporting education to developing and transitional economies. International Journal of Educational Development, 23(2), 215-232.

Boolaky, P.K. (2012). Accounting development and international financial reporting standards in small island economies: The case of Mauritius between 1960 and 2008. Journal of Accounting in Emerging Economies, 2(1), 4-29.

Bordo, M., Eichengreen, B., \& Irwin, D. A. (1999). Is Globalization Today Really Different than Globalization a Hundred Years Ago? Cambridge: National Bureau of Economic Research Working Paper 7195.

Borghesi, S., \& Vercelli, A.(2003). Sustainable globalisation. Ecological Economics, 44(1), 77-89.

Botzem, S. (2014). Transnational standard-setting in accounting: organizing expertise-based selfregulation in times of crises. Accounting, Auditing \& Accountability Journal, 27(6), 933-955.

Briston, R. (1978). The evolution of accounting in developing countries. International Journal of Accounting Education Research, 14(1), 105-120.

Busan Partnership for Effective Development Co-operation, (2011). Fourth High Level Forum on Aid Effectiveness. Busan: Republic of Korea.

Cammack, D. (2007). The Logic of African Neopatrimonialism: What Role for Donors? Development Policy Review, 25(5), 599-614.

Catchpowle, L., \& Cooper, C. (1999). No escaping the financial: The economic referent in South Africa. Critical Perspectives on Accounting, 10(6), 711-746.

Chand, P. (2005). Impetus to the success of harmonization: the case of South Pacific Island nations. Critical Perspectives on Accounting, 16(3), 209-226.

Chand, P., \& White, M. (2007). A critique of the influence of globalization and convergence of accounting standards in Fiji. Critical Perspectives on Accounting, 18(5), 605-622.

Chang, H-J. (2007). Bad Samaritans - The Guilty Secrets of Rich Nations \& the Threat to Global Prosperity. London: Random House Business Books.

Chua, W. F., \& Poullaos, C. (2002). The Empire Strikes Back? An exploration of centre-periphery interaction between the ICAEW and accounting associations in the self-governing colonies of 
Australia, Canada and South Africa, 1880-1907. Accounting, Organizations and Society, 27(4), 409445 .

Clapham, C. (1985). Third World Politics: an Introduction. London: Helm.

Chossudovsky, M. (2003). The Globalization of Poverty and the New World Order. Shanty Bay: Global Outlook.

Chwastiak, M. (2013). Profiting from destruction: The Iraq reconstruction, auditing and the management of fraud, Critical Perspectives on Accounting, 24(1), 32-43.

Clarke, G. (1998). Non-Governmental Organizations (NGOs) and Politics in the Developing World. Political Studies, 46(1), 36-52.

Cobham, A., \& McNair, D. (2012). The role of rich countries in development: the case for reforms. In T. Hopper, M. Tsamenyi, S. Uddin, \& D. Wickramasinghe (Eds.), Handbook of Accounting and Development. Cheltenham: Edward Elgar Publishing.

Commander, S., \& Killick, T. (1988). Privatization in developing countries: a survey of the issues. In G. Yarrow, \& P. Jasinski (Eds.), Privatization - Critical Perspectives on the World Economy. New York: Routledge.

Cook, P., \& Kirkpatrick, C. H. (1995). Privatisation policy and performance: international perspectives. London: Prentice-Hall.

Cooper, D. J., \& Ezzamel, M. (2013). Globalization discourses and performance measurement systems in a multinational firm. Accounting, Organizations and Society, 38(4), 288-313.

Cornia, G. A. (1999). Liberalization, Globalization and Income Distribution. Working Paper No. 157, The United Nations University.

Covaleski, M. A., Dirsmith, M.W., \& Rittenberg, L. (2003). Jurisdictional disputes over professional work: the institutionalization of the global knowledge expert. Accounting, Organizations and Society, 28(4), 323-355.

Dembour, M. B. (2006). Who Believes in Human Rights? Reflections on the European Convention. Cambridge: Cambridge University Press.

de Renzio, P. (2006). Aid, Budgets and Accountability: A Survey Article. Development Policy Review, 24(6), 627-645.

De Villiers, C., \& Van Staden, C. J. (2006). Can less environmental disclosure have a legitimising effect? Evidence from Africa. Accounting, Organizations and Society, 31(8), 763-781.

Devine, J. (2006). NGOs, Politics and Grassroots Mobilisation Evidence from Bangladesh. Journal of South Asian Development, 1(1), 77-99.

DiFazio, W. (1998). Poverty, the postmodern and the jobless future. Critical Perspectives on Accounting, 9(1), 57-74.

Ding, S., \& Graham, C. (2007). Accounting and the reduction of state-owned stock in China. Critical Perspectives on Accounting, 18(5), 559-580.

Dixon, R., Ritchie, J., \& Siwale, J. (2006). Microfinance: accountability from the grassroots, Accounting, Auditing \& Accountability Journal, 19(3), 405-427.

Djelic, M. L., \& Sahlin-Andersson, K. (Eds.). (2006). Transnational governance: Institutional dynamics of regulation. Cambridge: Cambridge University Press. 
Douzinas, C. (2000). The End of Human Rights: Critical Thought at the Turn of the Century. Portland: Hart Publishing.

Douzinas, C. (2007). Human Rights and Empire: The Political Philosophy of Cosmopolitanism. New York: Routledge-Cavendish.

Dyball, M. C., Poullaos, C., \& Chua, W. F. (2007). Accounting and empire: Professionalization-asresistance: The case of Philippines. Critical Perspectives on Accounting, 18(4), 415-449.

Edwards, M., \& Hulme, D. (1995). Non-governmental organisations: Performance and accountability beyond the magic bullet. London: Earthscan Publications.

Edwards, M., \& Hulme, D. (1996). Too close for comfort? The impact of official aid on nongovernmental organizations. World Development, 24(6), 961-973.

Eisenstadt, S. N. (1973). Traditional Patrimonialism and Modern Neo-Patrimonialism. London: Sage Publications Ltd.

Ekeh, P. (1975). Colonialism and the Two Publics in Africa: A Theoretical Statement. Comparative Studies in Society and History, 17(1), 91-112.

Emmanuel, C. (2012). Exploring the transfer pricing conundrum. In T. Hopper, M. Tsamenyi, S. Uddin, \& D. Wickramasinghe, (Eds.), Handbook of Accounting and Development. Cheltenham: Edward Elgar Publishing.

Enthoven, A.J.H. (1973). Accountancy and economic development policy. Amsterdam: North-Holland Publishing Co.

Enthoven, A.J.H. (1982). International management accounting: its scope and standards. The International Journal of Accounting, 17(2), 59-74.

Erdmann, G., \& Engel, U. (2007). Neopatrimonialism Reconsidered: Critical Review and Elaboration of an Elusive Concept. Journal of Commonwealth and Comparative Politics, 45(1), 95-119.

Esposito, D., Aronowitz. S., Chancer, L, DiFazio, W., \& Yard, M. (1998). The (In) Spectre returns! Global capitalism and the future of work. Critical Perspectives on Accounting, 9(1), 7-54.

Everett J. (2003). Globalization and its New Spaces for (Alternative) Accounting Research. Accounting Forum, 27(4), 400-424.

Everett, J. (2012). Corruption in the developing countries: 'thinking about' the role of accounting. In T. Hopper, M. Tsamenyi, S. Uddin, \& D. Wickramasinghe, (Eds.), Handbook of Accounting and Development. Cheltenham: Edward Elgar Publishing.

Everett, J., \& Friesen, C. (2010). Humanitarian accountability and performance in the Théatre de l'Absurde. Critical Perspectives on Accounting, 21(6), 468-485.

Everett, J., Neu, D., \& Rahaman, A. S. (2007). Accounting and the global fight against corruption, Accounting, Organizations and Society, 32(6), 513-542.

Firth, M. (1996). The diffusion of managerial accounting procedures in the People's Republic of China and the influence of foreign partnered joint ventures. Accounting, Organizations and Society, 21(7-8), 629-654.

Fisher, J. (1998). Nongovernments: NGOs and the Political Development of the Third World. West Hartford: Kumarian Press.

Friedrichs, D. O., \& Friedrichs, J. (2002). The World Bank and Crimes of Globalization: A Case Study. Globalization and Environmental Harm, 29(1/2), 13-36. 
Froud, J., Johal, S., Leaver, A., \& Williams, K. (2014). Financialization across the Pacific: Manufacturing cost ratios, supply chains and power. Critical Perspectives on Accounting, 25(1), 4657.

Fyson, S. (2012). Accounting and Development: the role of donors from policy to practice. In T. Hopper, M. Tsamenyi, S. Uddin, \& D. Wickramasinghe (Eds.), Handbook of Accounting and Development. Cheltenham: Edward Elgar Publishing.

Gallhofer, S., Haslam, J., \& Kamla, R. (2011). The accountancy profession and the ambiguities of globalisation in a post-colonial, Middle Eastern and Islamic context: Perceptions of accountants in Syria. Critical Perspectives on Accounting, 22(4), 376-395.

Ghartey, J. B. (1985). Accountability, the threshold of political instability and underdevelopment misery: the case of Africa. The International Journal of Accounting and Education Research, 21, 143 58.

Gibelman, M., \& Gelman, S. R. (2004). A Loss of Credibility: Patterns of Wrongdoing Among Nongovernmental Organizations. Voluntas: International Journal of Voluntary and Nonprofit Organizations. 15(4), 355-381.

Goddard, A., \& Assad, M. J. (2006). Accounting and navigating legitimacy in Tanzanian NGOs. Accounting, Auditing and Accountability Journal, 19(3), 377-404.

Goddard, A., \& Malagila, J. (2015). Public Sector External Auditing in Tanzania: A Theory of Managing Colonising Tendencies. In The Public Sector Accounting, Accountability and Auditing in Emerging Economies (pp. 179-222). Emerald Group Publishing Limited.

Goddard, A., \& Mzenzi, S. I. (2015). Accounting Practices in Tanzanian Local Government Authorities: Towards a Grounded Theory of Manipulating Legitimacy. In The Public Sector Accounting, Accountability and Auditing in Emerging Economies (pp. 109-142). Emerald Group Publishing Limited.

Goddard, A., Assad, M., Isa, S., Malagila, J., \& Mkasiwa, T. A. (2015). The 'two publics' and institutional theory - A study of public sector accounting in Tanzania. Critical Perspectives on Accounting, (In press).

Goldin, I., \& Van der Mensbrugghe, D. (1992). Trade Liberalization: What's At Stake? OECD Development Centre Policy Brief No. 5, OECD.

Gordon, L.A., Loeb, M. P, \& Zhu,W. (2012). The impact of IFRS adoption on foreign direct investment. Journal of Accounting and Public Policy, 31(4), 374-398.

Graham, C., \& Annisette, M. (2012). The role of transnational institutions in framing accounting in the Global South. In T. Hopper, M. Tsamenyi, S. Uddin, \& D. Wickramasinghe (Eds.), Handbook of Accounting and Development. Cheltenham: Edward Elgar Publishing.

Granell, E. (2000). Culture and globalisation: a Latin American challenge. Industrial and Commercial Training, 32(3), 89-94.

Gray, R., \& Gray, S. (2011). Accountability and human rights: A tentative exploration and a commentary, Critical Perspectives on Accounting, 22(8), 781-789.

Gray, R., Bebbington, J., \& Collison, D. (2006). NGOs, civil society and accountability: making the people accountable to capital. Accounting, Auditing \& Accountability Journal, 19(3), 319-348.

Guillen, M. F. (2001). Is Globalization Civilizing, Destructive or Feeble? A Critique of Five Key Debates in the Social Science Literature. Annual Review of Sociology, 27, 235-260. 
Gul, F. A., Wu, D., \& Yang, Z. (2013). Do Individual Auditors Affect Audit Quality? Evidence from Archival Data. The Accounting Review, 88(6), 1993-2023.

Hammond, T., Clayton, B. M., \& Arnold, P. J. (2009). South Africa's transition from apartheid: The role of professional closure in the experiences of black chartered accountants. Accounting, Organizations and Society, 34(6-7), 705-721.

Hammond, T., Clayton, B. M., \& Arnold, P. J. (2012). An "unofficial" history of race relations in the South African accounting industry, 1968-2000: Perspectives of South Africa's first black chartered accountants. Critical Perspectives on Accounting, 23(4-5), 332-350.

Hanlon, G. (1994). The commercialisation of accountancy: Flexible accumulation and the transformation of the service class. London: Palgrave Macmillan; 1994.

Harrison, G. (2004). The World Bank and Africa: The Construction of Governance States. London: Routledge.

Harvey, D. (1989). Time-varying conditional covariances in tests of asset pricing models. Journal of Financial Economics, 24(2), 289-317.

Hecht, S. B., Kandel, S., Gomes, I., Cuellar, N., \& Rosa, H. (2006). Globalization, Forest Resurgence, and Environmental Politics in El Salvador. World Development, 34(2), 308-323.

Herrmann, I. T., \& Hauschild, M. Z. (2009). Effects of globalisation on carbon footprints of products. CIRP Annals - Manufacturing Technology, 58(1), 13-16.

Himick, D. (2009). Accounting and Chilean pension reform. Accounting, Auditing \& Accountability Journal, 22(3), 405-428.

Hopper, T. (2016). Neopatrimonialism, Good Governance, Corruption and Accounting in Africa: Idealism versus Pragmatism. Journal of Accounting in Emerging Economies, forthcoming.

Hopper, T., Tsamenyi, M., Uddin, S., \& Wickramasinghe, D. (2009). Management Accounting in Less Developed Countries: What Is Known and Needs Knowing. Accounting, Auditing \& Accountability Journal, 22(3), 469-514.

Hopper, T., Tsamenyi, M., Uddin, S., \& Wickramasinghe, D. (Eds.) (2012). Handbook of Accounting and Development. Cheltenham: Edward Elgar Publishing

Hoque, Z. (1995). Budgetary control systems in public sector enterprises in a less developed country: some evidence from Bangladesh. International Journal of Accounting, 3, 344-355.

Hoque, Z., \& Hopper, T. (1994). Rationality, accounting and politics: a case study of management control in a Bangladeshi jute mill. Management Accounting Research, 5(5), 5-30.

Hoque, Z., \& Hopper, T. (1997). Political and industrial relations turbulence, competition and budgeting in the nationalized jute mills of Bangladesh. Accounting and Business Research, 27(2), $125-143$.

Hossain, M., Hossain, M., \& Sen, K. (2012). Accounting standards and capital market development. In T. Hopper, M. Tsamenyi, S. Uddin, \& D. Wickramasinghe, (Eds.), Handbook of Accounting and Development. Cheltenham: Edward Elgar Publishing.

Howell, J. (2002). In their own image: Donor assistance to civil society. In Lusotopie (Ed.), Les organisation non gouvernementales en lusophonie - Terrains et debats. Paris: Karthala. 
Humphrey, C., Loft, A., \& Woods, M. (2009). The global audit profession and the international financial architecture: Understanding regulatory relationships at a time of financial crisis. Accounting, Organizations and Society, 34(6-7), 810-825.

Intergovernmental Panel on Climate Change. (1995). Climate Change 1995: The Science of Climate Change - Contribution of Working Group 1 to the Second Assessment Report of the Intergovernmental Panel on Climate Change. Cambridge: Cambridge University Press.

Islam, M. A., \& Deegan, C. (2008). Motivations for an organisation within a developing country to report social responsibility information: Evidence from Bangladesh. Accounting, Auditing \& Accountability Journal, 21(6), 850-874.

Islam, M. A., \& McPhail, K. (2011). Regulating for corporate human rights abuses: The emergence of corporate reporting on the ILO's human rights standards within the global garment manufacturing and retail industry. Critical Perspectives on Accounting, 22(8,790-810.

Iyoha, F. O., \& Oyerinde, D. (2010). Accounting Infrastructure and Accountability in the Management of Public Expenditure in Developing Countries: A Focus on Nigeria. Critical Perspectives on Accounting, 21(5), 361-373.

Jacobs, K., Habib, M., Musyoki, N., \& Jubb, C. (2012). Empowering or oppressing: The case of microfinance institutions. In T. Hopper, M. Tsamenyi, S. Uddin, \& D. Wickramasinghe, (Eds.), Handbook of Accounting and Development. Cheltenham: Edward Elgar Publishing.

Jayasinghe, K., \& Thomas, D. (2009). The preservation of indigenous accounting systems in a subaltern community. Accounting, Auditing \& Accountability Journal, 22(3), 351-378.

Jayasinghe, K., \& Wickramasinghe, D. (2011). Power over empowerment: Encountering development accounting in a Sri Lankan fishing village. Critical Perspectives on Accounting, 22(4), 396-414.

Jordan, L., \& Van Tuijl, P. (2000). Political Responsibility in Transnational NGO Advocacy. World Development, 28(12), 2051-2065.

Joseph, R. (1976). The Gaullist Legacy: Patterns of French Neo-Colonialism. Review of African Political Economy, 6, 4-13.

Josiah J., Burton, B., Gallhofer, S., \& Haslam, J. (2010). Accounting for privatisation in Africa? Reflections from a critical interdisciplinary perspective. Critical Perspectives on Accounting, 21(5), 374-389.

Kapur, G. (1997). Globalisation and Culture. Third Text, 11(39), 21-38.

Kelsall, T. (2011). Rethinking the Relationship between Neo-Patrimonialism and Economic Performance in Sub-Saharan Africa. IDS Bulletin 42(2), 76-87.

Komori, N. (2015). Beneath the globalization paradox: Towards the sustainability of cultural diversity in accounting research. Critical Perspectives on Accounting, 26, 141-156.

Kuasirikun, N., \& Sherer, M. (2004). Corporate social accounting disclosure in Thailand. Accounting, Auditing \& Accountability Journal, 17(4), 629-660.

Kuasirikun, N. (2011). The portrayal of gender in annual reports in Thailand. Critical Perspectives on Accounting, 22(1), 53-78.

Lash, S., \& Urry, J. (1994). Economies of Signs \& Space. London: Sage. 
Lassou, P. J. C. (2014). International Political Economy: North-South Relations and Neo-colonialism - France 'Pushing' Through an Accounting Reform in Its Former African Colony. European Accounting Association Annual Congress, Tallinn; May 20-22.

Lassou P.J.C., Tsamenyi M. \& Hopper T. (2014) Political Economy of Accounting and Governance in Africa. Paper presented at the Critical Perspectives on Accounting Conference 2014, Toronto, 7-9 July.

Lauwo, S., \& Otusanya, O. J. (2014). Corporate accountability and human rights disclosures: A case study of Barrick Gold Mine in Tanzania, Accounting Forum, 38(2), 91-108.

Lehman, G. (2005). A critical perspective on the harmonisation of accounting in a globalising world, Critical Perspectives on Accounting,16(7), 975-992.

Lehman, G. (2007). The accountability of NGOs in civil society and its public spheres. Critical Perspectives on Accounting, 18(6), 645-669.

Lehman, G. (2009). Globalisation and the internationalisation of accounting: New technologies, instrumentalism and harmonisation. Critical Perspectives on Accounting, 20(4), 445-447.

Lemarchand, R., \& Legg, K. (1972). Political Clientelism and Development: a Preliminary Analysis. Comparative Politics, 4 (2), 149-178.

Le Vine, V. T. (1980). African Patrimonial Regimes in Comparative Perspective. Journal of Modern African Studies, 18(4), 657-673.

Lewis, D. (2001). Civil society in non-Western contexts: reflections on the 'usefulness' of a concept. Civil Society Working Paper series, 13. Centre for Civil Society. London: London School of Economics and Political Science.

Lodhia, S. K. (2003). Accountants' responses to the environmental agenda in a developing nation: An initial and exploratory study on Fiji. Critical Perspectives on Accounting, 14(7), 715-737.

Loft, A., Humphrey, C., \& Turley, S. (2006). In pursuit of global regulation: Changing governance and accountability structures at the International Federation of Accountants (IFAC). Accounting, Auditing \& Accountability Journal, 19(3), 428-451.

Lowder, S. (1999). Globalisation of the Footwear Industry: A Simple Case of Labour? Tijdschrift voor Economische en Sociale Geografie, 90(1), 47-60.

Lynch, G., \& Crawford, G. (2011). Democratization in Africa 1990-2010: An Assessment. Democratization, 18(2), 275-310.

Mahadeo, J.D., Oogarah-Hanuman, V., \& Soobaroyen, T. (2011). Changes in social and environmental reporting practices in an emerging economy (2004-2007): Exploring the relevance of stakeholder and legitimacy theories. Accounting Forum, 35(3), 158-175.

Maltby, J., \& Tsamenyi, M.(2010) Narrative accounting disclosure: Its role in the gold mining industry on the Gold Coast 1900-1949. Critical Perspectives on Accounting, 21(5), 390-401.

Marginson, S. (2006). Dynamics of National and Global Competition in Higher Education. Higher Education, 52(1), 1-39.

Martens, P., \& Raza, M. (2010). Is Globalisation Sustainable? Sustainability, 2(1), 280-293.

Martin, G. (1995). Continuity and Change in Franco-African Relations. The Journal of Modern African Studies, 33(1), 1-20. 
Maunders, K., Gray, R., \& Owen, D. (1990). Managerial social accounting in less developed countries: towards the operation of social reporting. Research in Third World Accounting, 1, 87-101.

McGuigan, J. (2005). Neo-Liberalism, Culture and Policy. International Journal of Cultural Policy, $11(3), 229-241$.

McMichael, P. (2007). Globalization and the Agrarian World. In G. Ritzer, (Ed.), The Blackwell Companion to Globalization. Malden: Blackwell Publishing.

McPhail, K., \& McKernan J. (2011). Accounting for human rights: An overview and introduction. Critical Perspectives on Accounting; 22(8), 733-737.

Médard, J. F. (1983). La Spécificité des Pouvoirs Africains. Pouvoirs, 25, 5-22.

Megginson, W. L, \& Sutter, N. L. (2006). Privatisation in Developing Countries. Corporate Governance: An International Review, 14(4), 234-265.

Mercer, C. (2002). NGOs, civil society and democratization: a critical review of the literature. Progress in development studies, 2(1), 5-22.

Meschi, E., \& Vivarelli, M. (2009). Trade and Income Inequality in Developing Countries. World Development, 37(2), 287-302.

Mihret, D.G., James K, \& Mula JM. (2012). Accounting professionalization amidst alternating state ideology in Ethiopia. Accounting, Auditing \& Accountability Journal, 25(7), 1206-1233.

Mir, M. Z., \& Rahaman, A. S. (2005). The adoption of international accounting standards in Bangladesh: An exploration of rationale and process. Accounting, Auditing \& Accountability Journal, 18(6), 816-841.

Mitlin, D., Hickey, S., \& Bebbington, A. (2007). Reclaiming Development? NGOs and the Challenge of Alternatives. World Development, 35(10), 1699-1720.

Molisa, P., Vandangombo, D., \& Brown, J. (2012). Social and environment accounting in developing countries - challenges, conflicts and contradictions. In T. Hopper, M. Tsamenyi, S. Uddin, \& Wickramasinghe, (Eds.), Handbook of Accounting and Development. Cheltenham: Edward Elgar Publishing.

Murphy, J. (2008). International financial institutions and the new global managerial order. Critical Perspectives on Accounting, 19(5), 714-740.

Narula, R., \& Dunning, J. H. (2000). Industrial development, globalization and multinational enterprises: new realities for developing countries. Oxford development studies, 28(2), 141-167.

Ndzinge, S., \& Briston, R. J. (1999). Accounting and economic development. Research in Accounting in Emerging Economies, 1, 29-42.

Needles, B. E. (1976). Implementing a framework for the international transfer of accounting technology. Journal of Accounting Education and Research, 12, 45-62.

Nepstad, D. C., Stickler, C. M., \& Almeida, O. T. (2006). Globalization of the Amazon soy and beef industries: opportunities for conservation. Conservation Biology, 20(6), 1595-1603.

Neu, D. (2000). Accounting and accountability relations: colonization, genocide and Canada's first nations. Accounting, Auditing \& Accountability Journal, 13(3), 268-288.

Neu, D., \& Heincke, M. (2004). The subaltern speaks: financial relations and the limits of governmentality. Critical Perspectives on Accounting, 15(1), 179-206. 
Neu, D., \& Ocambo, E. Doing missionary work: The World Bank and the diffusion of financial practices. Critical Perspectives on Accounting, 18(3), 363-389.

Neu, D., Everett, J., \& Rahaman, A. S. (2009). Accounting assemblages, desire, and the body without organs: A case study of international development lending in Latin America. Accounting, Auditing \& Accountability Journal, 22(3), 319-350.

Neu, D., Silva, L., \& Gomez, E. O. (2008). Diffusing financial practices in Latin American higher education. Accounting, Auditing \& Accountability Journal, 21 (1), 49-77.

Neu, D., Gomez, E. O., Graham, C., \& Heincke, M. (2006). "Informing" technologies and the World Bank. Accounting, Organizations and Society, 31(7), 635-662.

Neu, D., Rahaman, A. S., Everett, J., \& Akindayomi, A. (2010). The sign value of accounting: IMF structural adjustment programs and African banking reform. Critical Perspectives on Accounting, 21(5), 402-419.

Nissanke, M., \& Thorbecke, E. (2006). Channels and Policy Debate in the Globalization-InequalityPoverty Nexus. World Development, 34(8), 1338-1360.

Nnadi, M., \& Soobaroyen, T. (2015). International financial reporting standards and foreign direct investment: The case of Africa. Advances in Accounting, 31(2), 228-238.

O'Connor, N. G., Chow, C. W., \& Wu, A. (2004). The adoption of "Western" management accounting/controls in China's state-owned enterprises during economic transition. Accounting, Organizations and Society, 29(3-4), 349-375.

O'Connor, N. G., Deng, J., \& Luo, Y. (2006). Political constraints, organization design and performance measurement in China's state-owned enterprises, Accounting, Organizations and Society, $31(2), 157-177$.

O'Dwyer, B. (2005). The construction of a social account: a case study in an overseas aid agency. Accounting, Organizations and Society, 30(3), 279-296.

O'Dwyer, B., \& Unerman, J. (2008). The paradox of greater NGO accountability: A case study of Amnesty Ireland. Accounting, Organizations and Society, 33(7-8), 801-824.

O'Dwyer, B., \& Unerman, J. (2010). Enhancing the role of accountability in promoting the rights of beneficiaries of development NGOs. Accounting and Business Research, 40(5), 451-471.

O’Dwyer, B., \& Unerman, J. (2012). Accounting and accountability for NGOs. In T. Hopper, M. Tsamenyi, S. Uddin, \& Wickramasinghe, (Eds.), Handbook of Accounting and Development. Cheltenham: Edward Elgar Publishing.

Otusanya, O. J. (2011). The role of multinational companies in tax evasion and tax avoidance: The case of Nigeria. Critical Perspectives on Accounting, 22(3), 316-332.

Paris Declaration, (2005). Second High Level Forum on Aid Effectiveness. Paris: France.

Parker, D., \& Kirkpatrick, C. (2005). Privatisation in Developing Countries: A Review of the Evidence and the Policy Lessons. The Journal of Development Studies, 41(4), 513-54.

Pearce, J. (2006). Development, NGOs, and civil society: The debate and its future. In D. Eade, (Ed.), Development, NGOs, and civil society. Oxford: Oxfam.

Perera, H. (1989). Accounting in developing countries: a case for localised uniformity. British Accounting Review, 21, 141-158. 
Perera, H. (2012). Adoption of international financial reporting standards in developing countries. In T. Hopper, M. Tsamenyi, S. Uddin, \& D. Wickramasinghe, (Eds.), Handbook of Accounting and Development. Cheltenham: Edward Elgar Publishing.

Peterson, S. (2007). Imperfect Systems - IFMISs in Africa. World Bank and CABRO Conference on Budget Management and Public Financial Accountability; Pretoria; June 18.

Pitcher, A., Moran, M. H., \& Johnston, M. (2009). Rethinking Patrimonialism and Neopatrimonialism in Africa. African Studies Review, 52(1), 125-156.

Poullaos, C. (2004). Globalisation, accounting critique and the university. Critical Perspectives on Accounting, 15(4-5), 715-730.

Poullaos, C., \& Uche, C. (2012). Accounting professionalization in developing countries. In T. Hopper, M. Tsamenyi, S. Uddin, \& D. Wickramasinghe, (Eds.), Handbook of Accounting and Development. Cheltenham: Edward Elgar Publishing.

Power, M. (1994). The audit explosion. London: Demos.

Power, M. (2010). Fair value accounting, financial economics and the transformation of reliability. Accounting and Business Research, 40(3), 197-210.

Rahaman, A. S., Everett, J., \& Neu, D. (2007). Accounting and the privatization of water services in developing countries. Accounting, Auditing \& Accountability Journal, 20(5), 637-670.

Rahaman, A.S., Lawrence, S., \& Roper, J. (2004). Social and environmental reporting at the VRA: institutionalised legitimacy or legitimation crisis? Critical Perspectives on Accounting, 15(1), 35-56.

Rahman, S. F. (1998). International accounting regulation by the United Nations: a power perspective. Accounting, Auditing \& Accountability Journal, 11(5), 593-623.

Rahmani, R. (2012). Donors, beneficiaries, or NGOs: whose needs come first? Development in Practice, 22(3), 295-304.

Ritzer, G. (2007). The Blackwell Companion to Globalization. Malden: Blackwell Publishing.

Robinson, M. (2006). The Political Economy of Governance Reforms in Uganda. Brighton: Institute of Development Studies.

Roth, G. (1968). Personal Rulership, Patrimonialism, and Empire-Building in the New States. World Politics, 20(2), 194-206.

Roy, A. (2010). Poverty capital: Microfinance and the making of development. London: Routledge.

Rama, M. (2002). Globalisation and workers in developing countries. Journal of the Statistical and Social Inquiry Society of Ireland, XXXI, 147-194.

Robertson, R. (1990). Mapping the Global Condition: Globalization as the Central Concept. Theory Culture Society, 7, 15-30.

Sachs, J. D., \& Warner, A. (1995). Economic Reform and the Process of Global Integration. Brookings Papers on Economic Activity, 1995(1), 1-118.

Samsonova-Taddei, A., \& Humphrey, C. (2014). Transnationalism and the transforming roles of professional accountancy bodies: Towards a research agenda. Accounting, Auditing \& Accountability Journal, 27(6), 903-932. 
Samuel, S., \& Manassian, A. (2011). The rise and coming fall of international accounting research. Critical Perspectives on Accounting, 22(6), 608-627.

Sannassee, R. V., Seetanah, B., \& Jugessur, J. (2014). Export-led growth hypothesis: a metaanalysis. The Journal of Developing Areas, 48(1), 361-385.

Saravanamuthu, K. (2004). What is measured counts: harmonized corporate reporting and sustainable economic development. Critical Perspectives on Accounting, 15(3), 295-302.

Sawkut, R., Sannassee, R.V., \& Fowdar, S. (2009). The net contribution of the Mauritian export processing zone using benefit-cost analysis. Journal of International Development, 21(3), 379-392.

Schiavo-Campo, S. (2009). Potemkin Villages: "The" Medium-Term Expenditure Framework in Developing Countries. Public Budgeting \& Finance, 29(2), 1-26.

Scholte, J. A. (2002). What Is Globalization? The Definitional Issue - Again. CSGR Working Paper No. 109/02, The University of Warwick.

Scott, J. (1969). The Analysis of Corruption in Developing Nations. Comparative Studies in Society and History, 11(3), 315-341.

Seidler, L. J. (1967). International Accounting - The Ultimate Theory Course. The Accounting Review, 42(4), 775-781.

Seiler, R. E. (1966). Accounting, information systems, and underdeveloped nations. The Accounting Review, 41(4), 652-656.

Sian, S. (2011). Operationalising closure in a colonial context: The Association of Accountants in East Africa, 1949-1963. Accounting, Organizations and Society, 36(6), 363-381.

Siddique, J. (2012). Audit markets in less developed economies: caveats for globalisation? In T. Hopper, M. Tsamenyi, S. Uddin, \& D. Wickramasinghe, (Eds.), Handbook of Accounting and Development. Cheltenham: Edward Elgar Publishing.

Sikka, P. (2008). Globalization and its discontents: Accounting firms buy limited liability partnership legislation in Jersey. Accounting, Auditing \& Accountability Journal, 21(3), 398-426.

Sikka, P. (2011). Accounting for human rights: The challenge of globalization and foreign investment agreements. Critical Perspectives on Accounting, 22(8), 811-827.

Sikka, P., \& Willmott, H. (2010). The dark side of transfer pricing: Its role in tax avoidance and wealth retentiveness. Critical Perspectives on Accounting, 21(4), 342-356.

Soobaroyen, T., \& Ntim, C. G. (2013). Social and environmental accounting as symbolic and substantive means of legitimation: The case of HIV/AIDS reporting in South Africa. Accounting Forum, 37(2), 92-109.

Stiglitz, J. (2002). Globalization and its Discontents. New York: W.W. Norton \& Company.

Stiglitz, J. E. (2003). The Roaring Nineties: A New History of the World's Most Prosperous Decade. New York: W.W. Norton \& Company.

Suddaby, R., Cooper, D. J., \& Greenwood, R. (2007). Transnational regulation of professional services: Governance dynamics of field level organizational change. Accounting, Organizations and Society, 32(4), 333-362.

Sun, Y. (2014). Africa in China's Foreign Policy. Washington: Brookings. 
Susela, S. D. (1999). "Interests" and accounting standard setting in Malaysia. Accounting, Auditing \& Accountability Journal, 12(3), 358-387.

Sutherland, E. (2011). Republic of Benin-Chaos, Corruption and Development in Telecommunications. Info; 13(5), 63-85.

Tembo, F. (2003). The multi-image development NGO: An agent of the new imperialism? Development in Practice, 13(5), 527-532.

Temple, D. (1997). NGOs: a Trojan horse. In Rahnema M, Bawtree V. The Post-Development Reader, compiled and introduced. London: Zed Books.

Teoh, S. H., \& Zhang, Y. (2011). Data Truncation Bias, Loss Firms, and Accounting Anomalies. The Accounting Review, 86(4), 1445-1475.

Tinker, A. M. (1980). Towards a political economy of accounting: An empirical illustration of the Cambridge controversies. Accounting, Organizations and Society, 5(1), 147-160.

Townsend, J., \& Townsend, A. (2004). Accountability, motivation and practice: NGOs north and south. Social and Cultural Geography, 5(2), 271-285.

Tsamenyi, M., Onumah, J., \& Tetteh-Kumah, E. (2010). Post-privatization performance and organizational changes: Case studies from Ghana. Critical Perspectives on Accounting, 21(5), 428442.

Turner, M., \& Hulme, D. (1997). Governance, administration and development: Making the state work. Basingstoke: MacMillan.

Uche, C. U. (2002). Professional accounting development in Nigeria: threats from the inside and outside, Accounting, Organizations and Society, 27(4), 471-496.

Uddin, S. (2009). Rationalities, domination and accounting control: A case study from a traditional society. Critical Perspectives on Accounting, 20(6), 782-794.

Uddin, S., \& Hopper, T. (1999). Management control, ownership and development: experiences in privatised Bangladeshi enterprise. In M. Mackintosh, \& R. Roy, (Eds.), Macro-reforms and Microprocesses: Political Economy and Economic Management. London: Elgar.

Uddin, S., \& Hopper T. A. (2001). Bangladeshi Soap Opera: Privatisation, Accounting, and Regimes of Control in a Less Developed Country. Accounting, Organizations and Society, 26(7/8), 643-672.

Uddin, S., \& Hopper, T. (2003). Accounting for privatisation in Bangladesh: Testing World Bank claims. Critical Perspectives on Accounting, 14(7), 739-774.

Uddin, S., \& Tsamenyi, M. (2005). Public sector reforms and the public interest: A case study of accounting control changes and performance monitoring in a Ghanaian state-owned enterprise. Accounting, Auditing \& Accountability Journal, 18(5), 648-674.

Unerman, J., \& Bennett, M. (2004). Increased stakeholder dialogue and the internet: towards greater corporate accountability or reinforcing capitalist hegemony? Accounting, Organizations and Society, 29(7), 685-707.

Unerman, J., \& O'Dwyer, B. (2006). On James Bond and the importance of NGO accountability. Accounting, Auditing and Accountability Journal, 19(3), 305-318.

van Helden, J., \& Uddin, S. (2016). Public sector management accounting in emerging economies: A literature review. Critical Perspectives on Accounting. (in press). 
van Ufford, C., Giri, A. K., \& Mosse, D. (2003). Interventions in development: Towards a new moral understanding of our experiences and an agenda for the future. In C.van Ufford, \& A. K. Giri, (Eds.), A moral critique of development: In search of global responsibilities. London: Routledge.

Venter, E. R., \& De Villiers, C. (2013). The accounting profession's influence on academe: South African evidence. Accounting, Auditing \& Accountability Journal, 26(8), 1246-1278.

Vivian, J., \& Maseko, G. (1994). NGOs, participation and rural development: Testing the Assumptions with Evidence from Zimbabwe. Geneva: United Nations Research Institute for Social Development.

Vreeland, J. R. (2003). The IMF and Economic Development. Cambridge: Cambridge University Press.

Wallace, R.S.O. (1997). African Labour Systems, Maintenance Accounting and Agency Theory: Some Fundamental Questions. Critical Perspectives on Accounting, 8(4), 393-407.

Weber, M. (1947). The Theory of Social and Economic Organisations. New York: Free Press.

Welch, C., \& Oringer, J. (1998). Structural Adjustment Programs. Washington: Foreign Policy In Focus.

Wickramasinghe, D., \& Hopper, T. (2005). A cultural political economy of management accounting controls: a case study of a textile Mill in a traditional Sinhalese village. Critical Perspectives on Accounting, 16(4), 473-503.

Wolf, M. (2003). Is Globalisation in Danger? The World Economy, 26(4), 393-411.

Wootliff, J., \& Deri, C. (2001). NGOs: The new super brands. Corporate Reputation Review, 4(2), 157-165.

World Bank. (1992). Governance and Development. Washington DC: The World Bank.

World Bank. (1997). World Development Report 1997 - The State in a Changing World. New York: Oxford University Press.

World Bank. (2001). Framework for International Financial Architecture: An Update on World Bank Group Activities. Washington DC: World Bank.

World Bank. (2005). Framework for International Financial Architecture: A Progress Report. Washington DC: World Bank.

Wright, G. (2012). NGOs and Western hegemony: Causes for concern and ideas for change. Development in Practice, 22(1), 123-134.

Wynne, A. (2005). Public Financial Management Reforms in Developing Countries: Lessons of Experience from Ghana, Tanzania and Uganda. The African Capacity Building Foundation Working Paper No. 7.

Wynne, A. (2011). The General State Inspectorate - independent or under the executive - how does it compare with the Court of Accounts in Sub-Saharan Africa? International Consortium on Government Financial Management, 4, 93-130.

Wynne, A., \& Lawrence, S. (2012a). Accounting for Government in the Global South: do global solutions match local problems? Australasian Accounting, Business and Finance Journal, 3(2), 1-25.

Wynne, A., \& Lawrence, S. (2012b). Government Accounting in the Global South: The Design, Implementation and Use of Global Solutions for Local Needs. In T. Hopper, M. Tsamenyi, S. Uddin, 
\& D. Wickramasinghe (Eds.), Handbook of Accounting and Development. Cheltenham: Edward Elgar Publishing.

Yapa, P. W. S. (2006). Cross-border competition and the professionalization of accounting: the case of Sri Lanka. Accounting History, 11(4), 447-473.

Yee, H. (2009). The re-emergence of the public accounting profession in China: A hegemonic analysis. Critical Perspectives on Accounting, 20(1), 71-92.

Yee, H. (2012). Analyzing the state-accounting profession dynamic: Some insights from the professionalization experience in China. Accounting, Organizations and Society, 37(6), 426-444.

Zhang, Y., Andrew, J., \& Rudkin, K. (2012). Accounting as an instrument of neo-liberalisation? Exploring the adoption of fair value accounting in China. Accounting, Auditing \& Accountability Journal, 25(8), 1266-1289.

Zhou, Z. H. (1988). Chinese accounting systems and practices. Accounting, Organizations and Society, 13(2), 207-224.

Zolberg, A. R. (1969). Military Role and Political Development in Tropical Africa. In J. Doorn, (Ed.), The Military Profession and Military Regime. Mouton: The Hague. 